Prepared for the U.S. Department of Energy under Contract DE-AC05-76RL01830

\title{
Characteristics of STP Pre-2004 Archived KE Basin Sludge Samples Before and After Re-Jarring in the RPL - April 2012
}

\section{SI Sinkov}

CH Delegard

AJ Schmidt

JW Chenault

September 2012

Pacific Northwest

NATIONAL LABORATORY

Proudly Operated by Battelle Since 1965 


\title{
DISCLAIMER
}

This report was prepared as an account of work sponsored by an agency of the United States Government. Neither the United States Government nor any agency thereof, nor Battelle Memorial Institute, nor any of their employees, makes any warranty, express or implied, or assumes any legal liability or responsibility for the accuracy, completeness, or usefulness of any information, apparatus, product, or process disclosed, or represents that its use would not infringe privately owned rights. Reference herein to any specific commercial product, process, or service by trade name, trademark, manufacturer, or otherwise does not necessarily constitute or imply its endorsement, recommendation, or favoring by the United States Government or any agency thereof, or Battelle Memorial Institute. The views and opinions of authors expressed herein do not necessarily state or reflect those of the United States Government or any agency thereof.

\author{
PACIFIC NORTHWEST NATIONAL LABORATORY \\ operated by \\ BATTELLE \\ for the \\ UNITED STATES DEPARTMENT OF ENERGY \\ under Contract DE-AC05-76RL01830
}

Printed in the United States of America
Available to DOE and DOE contractors from the Office of Scientific and Technical Information,
P.O. Box 62, Oak Ridge, TN 37831-0062;
ph: (865) 576-8401
fax: $(865) 576-5728$
email: reports@adonis.osti.gov

\begin{abstract}
Available to the public from the National Technical Information Service, U.S. Department of Commerce, 5285 Port Royal Rd., Springfield, VA 22161 ph: (800) 553-6847 fax: (703) 605-6900 email: orders@ntis.fedworld.gov

online ordering: http://www.ntis.gov/ordering.htm
\end{abstract}

This document was printed on recycled paper. 


\section{Characteristics of STP Pre-2004 Archived KE Basin Sludge Samples Before and After Re-Jarring in the RPL - April 2012}

SI Sinkov

CH Delegard

AJ Schmidt

JW Chenault

September 2012

Prepared for

the U.S. Department of Energy

under Contract DE-AC05-76RL01830

Pacific Northwest National Laboratory

Richland, Washington 99352 



\section{Summary}

The Sludge Treatment Project (STP), managed for the U.S. Department of Energy (DOE) by CH2M Hill Plateau Remediation Company (CHRPC), is responsible for operating the K West (KW) Basin fuel storage pool and managing the sludge (and other materials) that it contains. The STP mission includes characterization, containment, safe removal, treatment, and transportation of all sludge (treated or untreated) from the KW Basin. Since the 1990s, samples of K Basin sludge have been collected during several sampling campaigns. In support of these campaigns, samples have been sent to the Pacific Northwest National Laboratory (PNNL) for characterization and process testing. At the request of the STP, sludge materials from these campaigns are being maintained and archived at PNNL as contingency for future testing requirements. Experience has shown that the archived sample materials have been very useful for the resolution of emerging issues as the sludge disposition path forward has evolved and as project design activities have been implemented. Experience has also shown that obtaining, transporting, and analyzing/testing new sludge sample material from $\mathrm{K}$ Basins remains a major investment for the $\mathrm{K}$ Basin project in terms of both time (years) and funds (millions of dollars).

This report describes results of work performed in the Shielded Analytical Laboratory (SAL) at the Pacific Northwest National Laboratory's (PNNL) Radiochemical Processing Laboratory (RPL) with archive K East (KE) Basin sludge samples obtained before the year 2004, with some of them composited and initially characterized five years ago (Delegard et al. 2011). The previously performed testing included the physical properties determinations for selected samples (settled and particle densities, water and solids concentrations), the $\mathrm{pH}$, as well as identification of crystalline phases by X-ray diffractometry (XRD) for selected samples. Another objective of the previous characterization and testing campaign was to transfer some sludge composites and individual samples into new storage containers to overcome the embrittlement effect which develops in original glass containers as a result of extended exposure to high radiation fields and which increases probability of sample loss.

With more than five years of storage of the abovementioned sludge samples in a hot-cell environment, concerns regarding gradually developing glass embrittlement and degradation of its mechanical strength were raised again and it was decided to transfer all valuable samples into new glass containers of unified geometry (240-ml Qorpak jars). This geometry is ideal for placement of groups of four to six samples inside of stainless steel bins available in the SAL for the long-term storage and regular inspection of archived samples. Some original samples available in amounts exceeding the capacity of a single 240-ml jar were split into two subsamples (denoted as X-jar and Y-jar) to accommodate all the content of the original container. Two subsamples of KC-6 organic ion exchange resin (OIER) beads held in the carboy in the High Level Radiochemistry Facility (HLRF) were taken and transferred to the SAL for more effective maintenance and utilization in future characterization and project testing. Finally, some samples of dry materials also were collected into 60-ml Qorpak jars. However, further discussion of these dry samples is not included in the present narrative because measurements of the materials' properties, aside from weight, were not made.

All new containers were calibrated with water using a clearly visible centimeter/millimeter ruled tape attached to their side walls. This approach allowed conversion of observed heights of water and sludge levels to their respective volumetric readings with a higher precision, which is important for more reliable calculation of settled sludge density. Results of the settled sludge density calculations are presented in Table S.1 below and compared where available with previously measured values. In general, the settled densities of the samples after transfer to the new containers are consistent with the settled densities determined five years ago.

Table S.2 summarizes data from sludge samples to be maintained as dry solids. 
Portions of supernatant water from each wet sludge sample before and after re-jarring were collected, transferred from a hot cell to a radiological fume hood, and processed for subsequent $\mathrm{pH}$ measurement and gamma energy analysis (GEA). All liquid subsamples were filtered through a $0.2-\mu \mathrm{m}$ syringe filter to eliminate any presence of suspended or colloidal matter in order to improve reliability of both $\mathrm{pH}$ measurements and fission product activity level determinations in the truly soluble fraction of the supernatant. It is noteworthy that the $\mathrm{pH}$ measurements in this study were performed with a higher-class instrument and $\mathrm{pH}$ electrode than a stick-type $\mathrm{pH}$ probe that had been used in the previous round of acidity determination in unfiltered sludge supernatants directly in a hot-cell environment. 
Table S.1. Sources and Properties of Re-Jarred KE Basin Sludge Samples

\begin{tabular}{|c|c|c|c|c|c|c|}
\hline \multirow[b]{2}{*}{ Sample ID } & \multirow{2}{*}{$\begin{array}{l}\text { Source (based on Table } 9.1 \text { comments } \\
\text { from the Delegard et al. } 2011 \text { report) }\end{array}$} & \multirow{2}{*}{$\begin{array}{l}\text { Re- } \\
\text { Jarring } \\
\text { Date }\end{array}$} & \multirow{2}{*}{$\begin{array}{l}\text { Settled } \\
\text { Volume, } \\
\mathrm{ml}\end{array}$} & \multirow{2}{*}{$\begin{array}{l}\text { U Dry } \\
\mathrm{Wt} \%\end{array}$} & \multicolumn{2}{|c|}{ Sludge Density, $\mathrm{g} / \mathrm{cm}^{3}$} \\
\hline & & & & & $\begin{array}{l}\text { Present Study } \\
\text { April } 2012\end{array}$ & \begin{tabular}{|c|} 
Previously \\
Determined $^{\mathrm{a}}$
\end{tabular} \\
\hline KC $2 / 3$ Comp & $\begin{array}{l}\text { Mixture of KC-2 and } \mathrm{KC}-3 \text { consolidated } \\
\text { sample with high to moderate damaged } \\
\text { fuel from all three bays }\end{array}$ & $\begin{array}{l}28 \mathrm{Mar} \\
2012\end{array}$ & $\begin{array}{l}185 \\
182\end{array}$ & 59.0 & $\begin{array}{l}2.02(\mathrm{X} \text { jar }) \\
2.35(\mathrm{Y} \text { jar })\end{array}$ & $\begin{array}{l}2.03 \text { (cone) } \\
2.14 \text { (jar) }\end{array}$ \\
\hline $96-05$ & $\begin{array}{l}\text { Single closed-bottom canister with very } \\
\text { poor condition fuel }\end{array}$ & $\begin{array}{l}27 \text { Mar } \\
2012\end{array}$ & 92 & 58.5 & 2.19 & $\begin{array}{l}1.77 \text { (cone) } \\
2.34\left(1997^{b}\right)\end{array}$ \\
\hline $\begin{array}{l}96-13 \text { Comp } \\
\text { A }\end{array}$ & $\begin{array}{l}\text { Composite of samples } 96-01,-05,-06 \\
-08,-13 \text {, and }-15 \text { from single canisters } \\
\text { with good to very poor condition fuel }\end{array}$ & $\begin{array}{l}27 \text { Mar } \\
2012\end{array}$ & 132 & 52.1 & 2.29 & 1.90 (cone) \\
\hline KE NLOP \#1 & \multirow{3}{*}{$\begin{array}{l}\text { KE North Load Out Pit; } \\
\text { top-to bottom sample composite present } \\
\text { in three jars }(\# 1, \# 2, \# 3)\end{array}$} & $\begin{array}{l}29 \mathrm{Mar} \\
2012\end{array}$ & 142 & \multirow{3}{*}{2.51} & 1.05 & \multirow{3}{*}{$\begin{array}{l}1.06(\text { cone }) \\
1.23\left(2004^{\mathrm{c}}\right)\end{array}$} \\
\hline KE NLOP \#2 & & $\begin{array}{l}28 \mathrm{Mar} \\
2012\end{array}$ & 200 & & 1.49 & \\
\hline KE NLOP \#3 & & $\begin{array}{l}29 \text { Mar } \\
2012 \\
\end{array}$ & 203 & & 1.72 & \\
\hline KC-4-2 & $\begin{array}{l}\text { Consol. sample from floor between } \\
\text { barrels of open bot. can w/highly } \\
\text { damaged fuel from all three bays }\end{array}$ & $\begin{array}{c}28 \mathrm{Mar} \\
2012\end{array}$ & $\begin{array}{r}142 \\
14\end{array}$ & 16.6 & $\begin{array}{l}1.48(\mathrm{X}-\mathrm{jar}) \\
1.19(\mathrm{Y} \text { jar})\end{array}$ & $\begin{array}{l}1.53 \text { (cone) } \\
1.60 \text { (jar) }\end{array}$ \\
\hline FE-5 Comp 1 & $\begin{array}{l}\text { Weasel pit including South Loadout Pit } \\
\text { Sludge }\end{array}$ & $\begin{array}{c}28 \mathrm{Mar} \\
2012\end{array}$ & $\begin{array}{r}164 \\
49\end{array}$ & 5.32 & $\begin{array}{l}1.68 \text { (X-jar) } \\
1.50 \text { (Y-jar) }\end{array}$ & $\begin{array}{l}1.66 \text { (cone) } \\
1.68 \text { (jar) }\end{array}$ \\
\hline $\begin{array}{l}\text { KE Floc } \\
\text { Comp }\end{array}$ & $\begin{array}{l}\text { Composite of KC-4 M250, KC-5, FE-5 } \\
\text { and KC Can Comp }\end{array}$ & $\begin{array}{l}28 \mathrm{Mar} \\
2012\end{array}$ & 132 & 10.3 & 1.35 & $\begin{array}{l}1.25 \text { (cone) } \\
1.30 \text { (jar) }\end{array}$ \\
\hline $\begin{array}{l}\text { 96-13 Solids } \\
\text { Grad }\end{array}$ & Single canister with poor condition fuel & $\begin{array}{l}28 \mathrm{Mar} \\
2012\end{array}$ & 67 & 74.0 & 2.23 & $\begin{array}{l}\text { No data } \\
2.458(1997)\end{array}$ \\
\hline 96-13 SSOL & Single canister with poor condition fuel & $\begin{array}{l}05 \mathrm{Apr} \\
2012\end{array}$ & 135 & 74.0 & 2.37 & $\begin{array}{l}\text { No data } \\
2.458(1997)\end{array}$ \\
\hline KC-4 Whole & $\begin{array}{l}\text { Consol. sample from floor between } \\
\text { barrels of open bot. can w/highly } \\
\text { damaged fuel from all three bays }\end{array}$ & $\begin{array}{l}28 \mathrm{Mar} \\
2012\end{array}$ & 89 & 16.6 & 1.73 & $\begin{array}{l}1.60 \text { (cone) } \\
1.56 \text { (jar) }\end{array}$ \\
\hline KE Pit & $\begin{array}{l}\text { Weasel Pit Composite of KES-P-16, } \\
\text {-Q-17, -R-18, -S-19, \& -T-20 }\end{array}$ & $\begin{array}{l}29 \text { Mar } \\
2012\end{array}$ & 107 & 7.99 & 1.92 & $\begin{array}{l}1.77 \text { (cone) } \\
1.92 \text { (jar) }\end{array}$ \\
\hline KC-4 P250 & $\begin{array}{l}>250 \mu \mathrm{m} \text { particle size fraction for wet } \\
\text { sieved KC-4 sludge }\end{array}$ & $\begin{array}{l}29 \text { Mar } \\
12\end{array}$ & 53 & No data & 1.51 & No data \\
\hline KC-1 M500 & $\begin{array}{l}\text { Canister sludge from highly damaged } \\
\text { fuel collected from one sampling location }\end{array}$ & $\begin{array}{l}29 \mathrm{Mar} \\
2012\end{array}$ & 21 & 68.6 & 2.31 & $\begin{array}{l}2.05 \text { (cone) } \\
2.66 \text { (jar) }\end{array}$ \\
\hline KC-6 & $\begin{array}{l}\text { Consol. sample from floor area in west } \\
\text { bay known to be v. high in ion exchange } \\
\text { beads }\end{array}$ & $\begin{array}{l}28 \mathrm{Mar} \\
2012\end{array}$ & 114 & 0.314 & 1.20 & $\begin{array}{l}1.31 \text { (cone) } \\
1.20 \text { (jar) }\end{array}$ \\
\hline KC-6 New & KC-6 Carboy material & $\begin{array}{l}27 \text { Mar } \\
2012\end{array}$ & $\begin{array}{l}117 \\
117\end{array}$ & 0.314 & $\begin{array}{l}1.21(\mathrm{X}-\mathrm{jar}) \\
1.36(\mathrm{Y}-\mathrm{jar})\end{array}$ & No data \\
\hline \multicolumn{7}{|c|}{$\begin{array}{l}\text { a) All data (unless indicated otherwise) are from: Delegard CH, AJ Schmidt, and JW Chenault. } 2011 . \\
\text { Characteristics of KE Basin Sludge Samples Archived in the RPL - 2007. PNNL-17078, Rev. 1, Pacific } \\
\text { Northwest National Laboratory, Richland, WA. }\end{array}$} \\
\hline \multicolumn{7}{|c|}{$\begin{array}{l}\text { b) Makenas BJ, TL Welsh, RB Baker, EW Hoppe, AJ Schmidt, J Abrefah, JM Tingey, PR Bredt, and GR Golcar. } \\
\text { 1997. Analysis of Sludge from Hanford K East Basin Canisters. HNF-SP-1201, DE\&S Hanford, Inc., Richland, } \\
\text { WA. }\end{array}$} \\
\hline \multicolumn{7}{|l|}{ c) } \\
\hline
\end{tabular}


Table S.2. Sludge Samples Being Maintained as Dry Solids

\begin{tabular}{|l|c|c|c|c|c|c|}
\hline \multicolumn{1}{|c|}{ Sample ID } & $\begin{array}{c}\text { Original Jar } \\
\text { Gross Weight, } \\
\mathrm{g}\end{array}$ & $\begin{array}{c}\text { Original Jar } \\
\text { Tare, g }\end{array}$ & $\begin{array}{c}\text { Net Amount in } \\
\text { Original Jar, g }\end{array}$ & $\begin{array}{c}\text { New Jar } \\
\text { Tare, g }\end{array}$ & $\begin{array}{c}\text { New Jar } \\
\text { Gross } \\
\text { Weight, g }\end{array}$ & $\begin{array}{c}\text { Net Amount } \\
\text { in New Jar, } \\
\mathrm{g}\end{array}$ \\
\hline $\begin{array}{l}\text { K Basin Fuel } \\
\text { Fines }\end{array}$ & 282.7 & 89.59 & 193.11 & - & - & - \\
\hline $\begin{array}{l}\text { K Basin Fuel } \\
\text { Fines M500 }\end{array}$ & - & - & - & 89.2 & 243.4 & 154.2 \\
\hline $\begin{array}{l}\text { K Basin Fuel } \\
\text { Fines P500 }\end{array}$ & - & - & - & 89.2 & 127.5 & 38.3 \\
\hline FE-3 Comp 1 & 240.3 & Not measured & $\begin{array}{c}\text { Cannot be } \\
\text { calculated }\end{array}$ & - & - & - \\
\hline FE-3 Comp 1 & - & - & - & 233.6 & 354.9 & 121.3 \\
\hline $\begin{array}{l}\text { SNF Comp } \\
\text { Settling Study }\end{array}$ & 274.6 & Not measured & $\begin{array}{c}\text { Cannot be } \\
\text { calculated }\end{array}$ & - & - & - \\
\hline $\begin{array}{l}\text { SNF Comp } \\
\text { Settling Study }\end{array}$ & - & - & - & 89.3 & 141.9 & 52.6 \\
\hline $\begin{array}{l}\text { Test 3 Residue } \\
\text { Test 3 Residue }\end{array}$ & - & Not measured & $\begin{array}{l}\text { Cannot be } \\
\text { calculated }\end{array}$ & - & - & - \\
\hline $\begin{array}{l}\text { 96-13 Settling } \\
\text { Study }\end{array}$ & 299.9 & Not measured & $\begin{array}{l}\text { Cannot be } \\
\text { calculated }\end{array}$ & - & - & - \\
\hline $\begin{array}{l}\text { 96-13 Settling } \\
\text { Study }\end{array}$ & - & - & - & 89.2 & 167.6 & 77.6 \\
\hline
\end{tabular}

Figure S.1 summarizes the $\mathrm{pH}$ data and ${ }^{137} \mathrm{Cs}$ activity measurements in all 33 filtered supernatants of 17 wet sludge samples available for analysis. For technical reasons it was not possible to produce sufficient amounts of supernatant of the "96-13 SSOL" sample before re-jarring. Figure S.1 also shows four points from the 1995 and $1996 \mathrm{KE}$ and K West (KW) sludge characterization studies (triangles) and three points associated with sludge transfers into the KE Weasel Pit (denoted in Figure S.1 as transfer activity [circles]). 


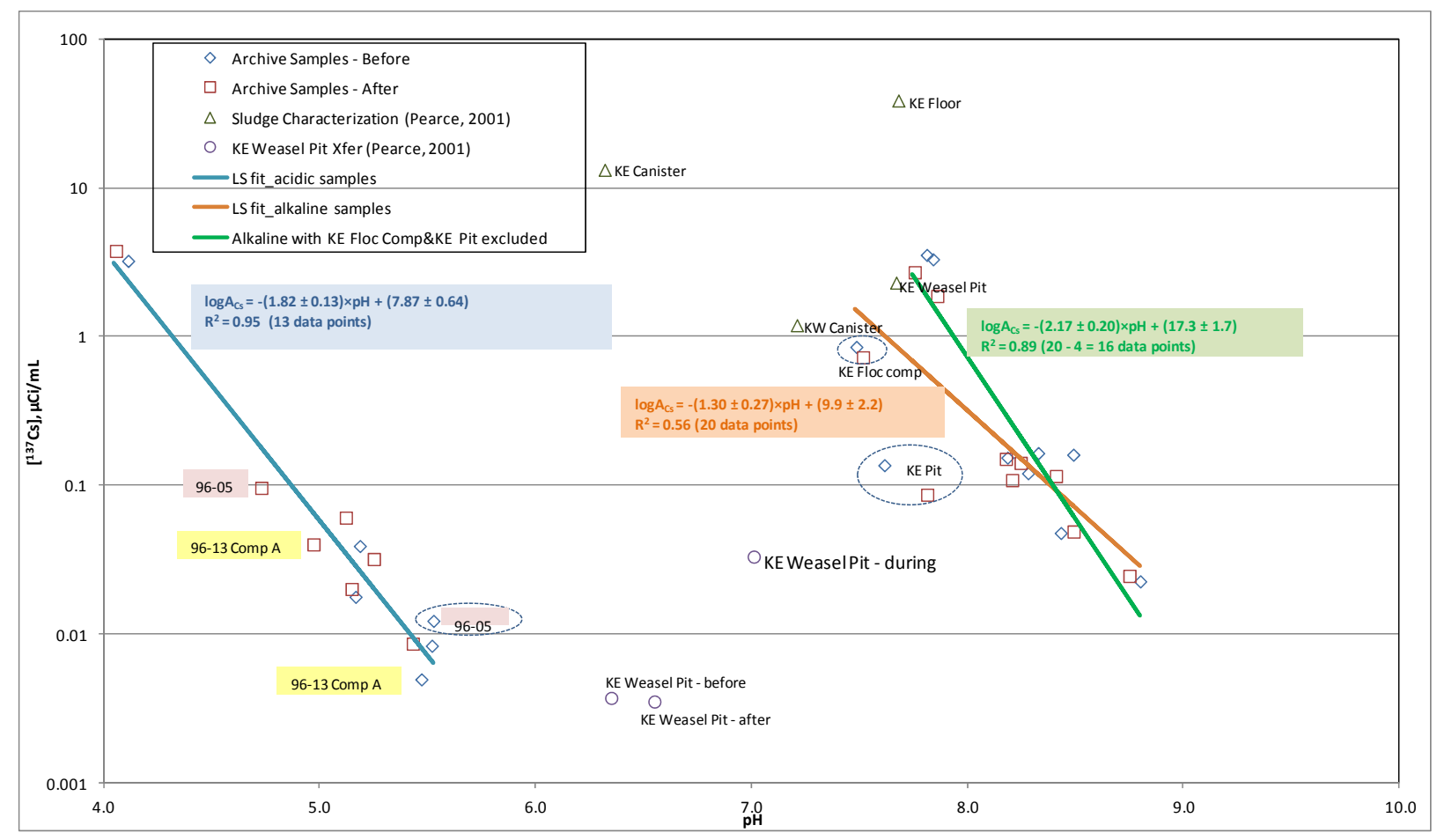

Figure S.1. $\quad{ }^{137}$ Cs Activity Levels in Filtered Sludge Supernatants Before and After Re-Jarring as a Function of $\mathrm{pH}$

Figure S. 1 is reproduced in a larger size in the Results and Discussion section with some comments on sample grouping for linear regression analysis. In the same section four other sets of data ${ }^{241} \mathrm{Am}$ concentrations vs. $\mathrm{pH}$, as well as ${ }^{137} \mathrm{Cs}, \mathrm{pH}$, and sludge density data vs. uranium concentration in sludge) are presented and discussed.

The major findings from these comparisons can be summarized as follows:

- $\quad{ }^{137} \mathrm{Cs}$ concentration values in supernatants given in the sludge characterization reports bracket the values obtained in the process of re-jarring of the archive sludges. The radiocesium values for the "Before," "During," and "After" transfers of KE Basin sludge to the KE Weasel Pit (from Table 4.2 in HNF-SD-SNF-TI-009, Pearce 2001) are at the low end of those observed in this round of archive sludge measurements, while the concentrations in the characterization of the K Basin waters (data from Table 4.1 in HNF-SD-SNF-TI-009, Pearce 2001) are at the high end of those observed in the archive sludge. Therefore, no evidence for leaching or displacement of ${ }^{137} \mathrm{Cs}$ from the sludge solids to the supernatant solution can be seen with aging.

- $\quad{ }^{137} \mathrm{Cs}$ activity levels in supernates of archived sludge samples appear to be sensitive functions of $\mathrm{pH}$. The following relationships were established by the linear least squares analysis of the obtained data:
o $\log \left[{ }^{137} \mathrm{Cs}, \mu \mathrm{Ci} / \mathrm{ml}\right]=-(1.82 \pm 0.13) \mathrm{pH}+(7.87 \pm 0.64)$ for $\mathrm{pH}$ range from 4.06 to 5.52
o $\log \left[{ }^{137} \mathrm{Cs}, \mu \mathrm{Ci} / \mathrm{ml}\right]=-(2.17 \pm 0.20) \mathrm{pH}+(17.3 \pm 1.7)$ for $\mathrm{pH}$ range from 7.66 to 8.80 
- No rigorous comparison of ${ }^{137} \mathrm{Cs}$ concentrations measured in recent sludge settling tests can be made with the data obtained in this study because of insufficient overlapping of $\mathrm{pH}$ regions (6.34-7.72 for settling tests vs. the 4.06-5.52 and 7.49-8.80 ranges for the re-jarring study).

- Sludge disturbance in the process of re-jarring does not increase ${ }^{137} \mathrm{Cs}$ activity level in 14 of the 16 sludge supernatants examined in this study. This conclusion is based on examination of ${ }^{137} \mathrm{Cs}$ activity ratio for the respective samples before and after-re-jarring as shown below:

o Average $\left[{ }^{137} \mathrm{Cs}\right]_{\mathrm{after}} /\left[{ }^{137} \mathrm{Cs}\right]_{\text {before }}$ ratio for all 16 samples: $1.99 \pm 3.12 / \sqrt{ } 16=1.99 \pm 0.78$

o The same ratio after exclusion of "96-05" and "96-13 Comp A" from averaging: $0.87 \pm 0.19 / \sqrt{ } 14=0.87 \pm 0.05$

- $\quad{ }^{241} \mathrm{Am}$ activity levels decrease very steeply (4.2 orders of magnitude), to $50 \mathrm{nCi} / \mathrm{ml}$, with $\mathrm{pH}$ elevation from 4.06 to 5.52 and remain at this level above $\mathrm{pH} 5.52$ for the weakly alkaline archive sludge supernatants. 


\section{Acronyms and Abbreviations}

CHPRC

DI

GEA

ID

HLRF

$\mathrm{KE}$

KW

OIER

PNNL

RPL

SAL

STP

TI

$\mu \mathrm{m}$

XRD
CH2M Hill Plateau Remediation Company

deionized

gamma energy analysis

identification

High Level Radiochemistry Facility

K East (Basin)

K West (Basin)

organic ion exchange resin

Pacific Northwest National Laboratory

Radiochemical Processing Laboratory

Shielded Analytical Laboratory

Sludge Treatment Project

test instruction

micrometers

X-ray diffractometry 



\section{Contents}

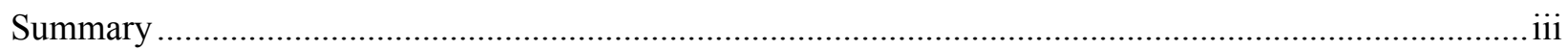

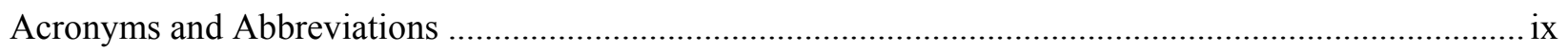

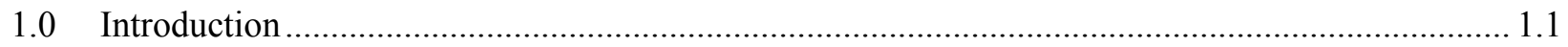

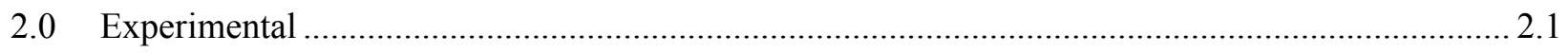

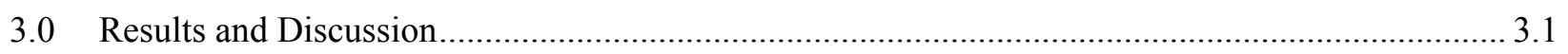

3.1 Sieved Fractions of K Basin Fuel Fines Sample............................................................. 3.1

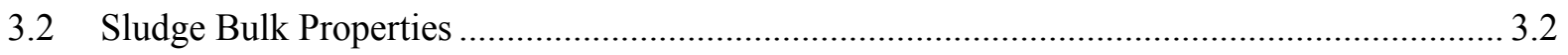

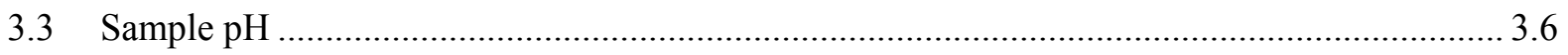

3.4 Fission Products and Transplutonium Metals Activity Levels in Sludge Supernatants

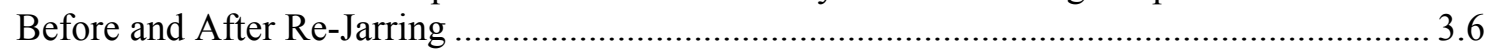

3.5 Gel Formation in the Mixture of Unfiltered Supernatants................................................... 3.14

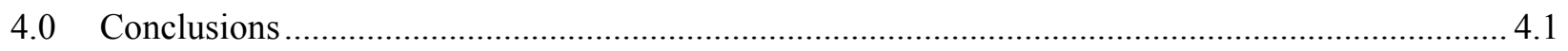

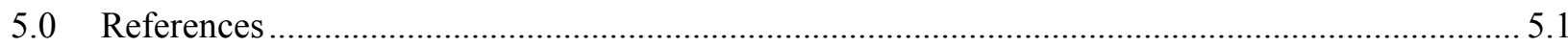

Appendix A: Addition of "SFEC 96-04" Fuel Sample to the Inventory of Pre-2004 K Basin Sample... A.1

Appendix B: Observations of Resin Beads After Re-Jarring............................................................... 1

\section{Figures}

S.1. ${ }^{137}$ Cs Activity Levels in Filtered Sludge Supernatants Before and After Re-Jarring as a Function of $\mathrm{pH}$

2.1. Calibration Chart for Qorpack 240-ml Bottle ....................................................................... 2.1

3.1. Photographs of Coarse Fraction of K Basin Fuel Material Taken from Different Angles and Distances a), b), and c); Image of Fine Fraction of K Basin Fuel Material d) ......................... 3.2

3.2. Sludge Density as a Function of Dry-Basis Uranium Concentration............................................ 3.3

3.3. ${ }^{137}$ Cs Activity Levels in Filtered Sludge Supernatants Before and After Re-Jarring

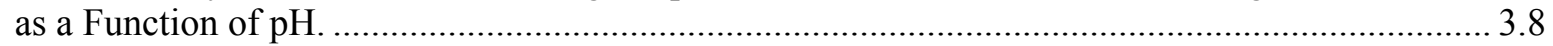

3.4. ${ }^{241}$ Am Activity Levels in Filtered Sludge Supernatants Before and After Re-Jarring as a Function of $\mathrm{pH}$

3.5. Adsorption of ${ }^{137} \mathrm{Cs}$ on Freshly Prepared Metal Hydroxides and on the Metal Hydroxides After Ten Days of Aging as a Function of the $\mathrm{pH}$ of the Solution: 1-Nb; 2-Ti; 3 - Fe; 4 - Sn; 5 - Zr; 6-Al; 7-Be, $\mathrm{Mg}$

3.6. ${ }^{137}$ Cs Activity Levels in Filtered Sludge Supernatants After Re-Jarring as a Function of Dry Basis Uranium Concentration

3.7. Sludge $\mathrm{pH}$ After Re-Jarring as a Function of Dry-Basis Uranium Concentration 


\section{Tables}

S.1. Sources and Properties of Re-Jarred KE Basin Sludge Samples .................................................... V

S.2. Sludge Samples Being Maintained as Dry Solids ............................................................................ vi

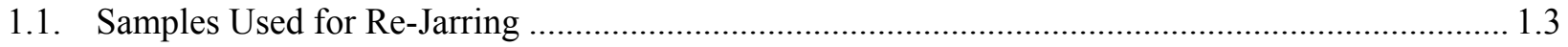

3.1. Settled Sludge Data and Calculated Densities for the First Seven Wet Samples Listed

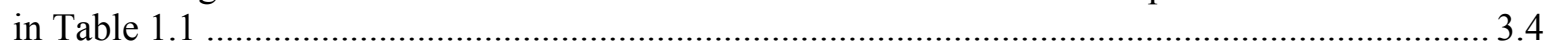

3.2. Settled Sludge Data and Calculated Densities for the Last Ten Wet Samples Listed

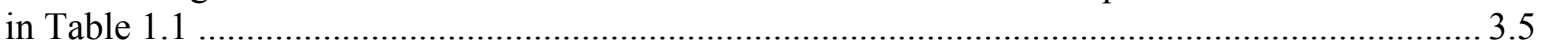

3.3. Acidity of KE Basin Sludge Supernatants Before and After Re-Jarring....................................... 3.6

3.4. ${ }^{137} \mathrm{Cs}$ and ${ }^{241} \mathrm{Am}$ Concentrations in Filtered Sludge Supernatants Before and

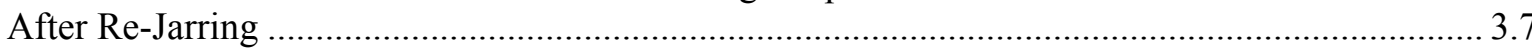

3.5. Acidity and ${ }^{137}$ Cs Concentrations in Filtrates of Engineered Containerized Sludge

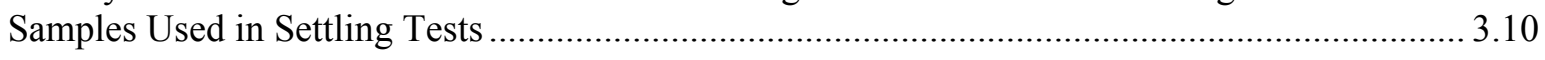




\subsection{Introduction}

\section{$\underline{\text { Background }}$}

The Sludge Treatment Project (STP), managed for the U.S. Department of Energy (DOE) by CH2M Hill Plateau Remediation Company (CHRPC), is responsible for operating the K West (KW) Basin fuel storage pool and managing the sludge (and other materials) that it contains. The STP mission includes characterization, containment, safe removal, treatment, and transportation of all sludge (treated or untreated) from the KW Basin. Since the 1990s, samples of K Basin sludge have been collected during several sampling campaigns. In support of these campaigns, samples have been sent to the Pacific Northwest National Laboratory (PNNL) for characterization and process testing. At the request of the STP, sludge materials from these campaigns are being maintained and archived at PNNL as contingency for future testing requirements. Experience has shown that the archived sample materials have been very useful for the resolution of emerging issues as the sludge disposition path forward has evolved and as project design activities have been implemented. Experience has also shown that obtaining, transporting, and analyzing/testing new sludge sample material from $\mathrm{K}$ Basins remains a major investment for the $\mathrm{K}$ Basin project in terms of both time (years) and funds (millions of dollars).

Some of the older (2003 and earlier) samples have high value for testing in that they represent compositions that may be unique and bounding for some sludge constituents relative to newer samples. The older K Basin sludge samples were collected from the original sludge locations in the K Basins, including the KE Basin floor, pits, and fuel storage canisters. In the KW Basin, older samples were collected from the KW fuel storage canisters. These samples represent the compositions of the original sludge sources and some are highly unique. Therefore, a limited number of older sludge samples that represent unique or bounding compositions are being retained. In addition, the samples that have been stored for prolonged times in the hot-cell environment may provide insights into the potential behavior of sludge after it has been stored at T Plant or another storage facility for many years, as currently is envisioned for the bulk sludge.

The work described in this report was prepared for CHPRC conducted under the Statement of Work for Contract 36402, Release 19, "Technical Services Providing Continued Storage of Sludge Samples," Amendment 0, executed September 30, 2008, (PNNL Project 46498). The sludge samples in this report are controlled under the Sampling and Analysis Plan developed in 2000 (Baker et al. 2000).

\section{Current Testing}

Samples of sludge were collected from the K East storage basin (KE basin) floor, contiguous pits, and fuel storage canisters between 1995 and 2003 for chemical and radionuclide concentration analysis, physical property determination, and chemical process testing work. Since their collection, consolidation, and characterization [Delegard et al. $2011^{(1)}$ ] in 2007, the samples had been stored in the High Level Radiochemistry Facility (HLRF) at hot cell temperatures $\left(\sim 30^{\circ} \mathrm{C}\right)$ until March 2012 , when they were transferred to the Shielded Analytical Laboratory (SAL). With more than five years of storage of the abovementioned sludge samples in a very high radiation environment, concerns regarding significant degradation of mechanical strength of the sludge containers were expressed.

\footnotetext{
${ }^{1}$ Delegard CH. 2011. "Characteristics of KE Basin Sludge Samples Archived in the RPL - 2007.” PNNL-17078 was initially issued as a project letter report in 2007. In 2011, it was reissued (as Revision 1) for Unlimited Distribution to provide enhanced traceability for key archived sludge samples that were collected from pre-2004 K Basin sludge sampling campaigns performed by the K Basin Project.
} 
The basic objectives of this work performed under Test Instruction (TI) 53451-TI42 have been to:

1) consolidate and upgrade the pre-2004 archived sludge sample inventory into new higher-integrity containers in the SAL

2) collect two additional subsamples of $\mathrm{KC}-6$ organic ion exchange resin (OIER) beads held in the carboy in the HLRF so that they can be effectively maintained and utilized for future characterization and project testing

3) examine the K Basin Fuel Fine sample and split it by sieving at $500 \mu \mathrm{m}$ to determine if a significant quantity of larger fuel fragments $(+500 \mu \mathrm{m})$ are available for potential corrosion rate studies

4) measure settled densities of the sludge samples after re-jarring

5) determine the $\mathrm{pH}$ of the filtered supernatant waters before and after re-jarring and compare with prior $\mathrm{pH}$ measurements to determine if significant alteration occurs by re-jarring and by storage time

6) measure concentrations of major gamma-emitters in the filtered supernatant waters associated with the wet archive sludges to assess potential dissolution/leaching of these radionuclides during sludge storage.

Table 1.1 shows the list of key and non-key samples that have undergone re-jarring in the course of the work covered under this document. The selection and differentiation of the key vs. non-key samples is documented in the Pacific Northwest National Laboratory (PNNL) Project Letter Report 46498-L15. ${ }^{2}$

\footnotetext{
${ }^{2}$ PNNL Project Letter 46498-L15. June 30, 2010. "Identification of Inventory of Pre-2004 K Basin Sludge Samples to Achieve to Support Ongoing Project Needed and Release of Remaining Samples for Disposal". Project Letter to JP Sloughter (CHPRC/STP) from AJ Schmidt (PNNL).
} 
Table 1.1 Samples Used for Re-Jarring

\begin{tabular}{|c|c|c|c|}
\hline Sample ID & Volume, ml, Jar/Sludge & Condition $^{(a)}$ & New ID \\
\hline \multicolumn{4}{|c|}{ Key Samples } \\
\hline KC-2/3 Comp & $1000 / 350$ & Wet; $500 \mathrm{ml}$ total volume & KC-2/3 Comp X; KC-2/3 Comp Y \\
\hline $96-05$ & $500 / 100$ & Wet; $300 \mathrm{ml}$ total volume & $96-05$ \\
\hline 96-13 KE Comp A & $500 / 125$ & Wet; $450 \mathrm{ml}$ total volume & 96-13 KE Comp A \\
\hline KE NLOP \#2 & $500 / 80$ & Wet; $400 \mathrm{ml}$ total volume & KE NLOP \#2 \\
\hline KC-4-2 & $500 / 160$ & Wet; $380 \mathrm{ml}$ total volume & KC-4-2 X; KC-4-2 Y \\
\hline KC-6 & $500 / 150$ & Wet; $300 \mathrm{ml}$ total volume & KC-6 \\
\hline FE-5 Comp 1 & $500 / 170$ & Wet; $325 \mathrm{ml}$ total volume & FE-5 Comp 1 X; FE-5 Comp 1 Y \\
\hline KE Floc Comp & $500 / 50$ & Wet; $250 \mathrm{ml}$ total volume & KE Floc Comp \\
\hline KC-6 New & Carboy & Wet; present in HLRF & KC-6 New X; KC-6 New Y \\
\hline K Basin Fuel Fines & $60 /$ not measured & Dry fuel/oxide particles & $\begin{array}{l}\text { K Basin Fuel Fines M500; } \\
\text { K Basin Fuel Fines P500 }\end{array}$ \\
\hline \multicolumn{4}{|c|}{ Non-Key Samples } \\
\hline 96-13 Solids Grad & $250 / 140$ & Wet; $160 \mathrm{ml}$ total vol.; chunk & 96-13 Solids Grad \\
\hline 96-13 SSOL & $500 / 100$ & Wet; $160 \mathrm{ml}$ total volume & 96-13 SSOL \\
\hline KC-4 Whole & $500 / 125$ & Wet; $250 \mathrm{ml}$ total volume & KC-4 Whole \\
\hline KE Pit & $500 / 125$ & Wet; $120 \mathrm{ml}$ total volume & KE Pit \\
\hline KE NLOP \#1 & $500 / 100$ & Wet; $450 \mathrm{ml}$ total volume & KE NLOP \#1 \\
\hline KE NLOP \#3 & $500 / 100$ & Wet; $300 \mathrm{ml}$ total volume & KE NLOP \#3 \\
\hline FE-3 Comp 1 & 500/not measured & Dry; cracked & FE-3 Comp 1 \\
\hline KC-4 P250 & $125 / 60$ & Wet; $80 \mathrm{ml}$ total volume & KC-4 P250 \\
\hline KC-1 M500 & $500 / 50$ & Wet; $100 \mathrm{ml}$ total volume & KC-1 M500 \\
\hline SNF Comp Stl Study & $250 / 50$ & Dry cake & SNF Comp Stl Study \\
\hline Test 3 Residue & $250 / 50$ & Dry cake & Test 3 Residue \\
\hline 96-13 Settling Study & $250 / 50$ & Dry rubble & 96-13 Settling Study \\
\hline
\end{tabular}





\subsection{Experimental}

Experimental activities performed in the course of this work include collection of supernatant solutions, determination of settled sludge volumes and masses (to also determine densities), removal of suspended solids from collected supernatant solutions, measurement of $\mathrm{pH}$ and concentrations of gamma emitters in the clarified supernatant solutions, and sieving of the irradiated fuel particle sample at $500 \mu \mathrm{m}$. These experimental activities are described in the following paragraphs.

Sludge transfer to new jar. Re-jarring of sludge samples was performed by transferring settled sludge portions from old jar to new jar using a remotely operated spoon shaped spatula followed by pouring the remaining aqueous sludge suspension into new container. All samples were agitated before this operation to loosen the settled sludge layer for more efficient transfer. In most cases amount of water initially present in original jar was sufficient to remove the remaining sludge layer from the bottom and walls of old jar by a gentle swirling of the remaining content of the sludge material. In some cases small amount of DI water was added to $\sim 90 \%$ unloaded old container to facilitate the residual sludge remobilization. For these samples amount of added water was typically less than $10 \mathrm{ml}$ which represented dilution factors of less than 1.1 with respect to the initial amount of aqueous supernatant present in the original sample.

Supernatant Sample. Portions of supernatant water from each wet sludge sample before and after re-jarring were collected, transferred from a hot cell to a radiological fume hood, and processed for the subsequent $\mathrm{pH}$ measurements and gamma energy analysis (GEA). The "before re-jarring" samples represent the state of the supernatant after being in contact with the sludge solids during quiescent storage for five years. After re-jarring, the sludge solid and supernatant were aggressively mixed/homogenized before collection of the "after re-jarring" supernatant samples.

Sludge Volume and Mass Determination and Density Calculation. Settled sludge and water levels were measured using a centimeter/millimeter ruled tape attached to the side wall of each new jar. All new jars had been volume-calibrated with water prior to their introduction to SAL. Figure 2.1 shows results of the calibration. The following relationship, established in the course of calibration for a 240-ml jar, was used for conversion of sludge and water levels to their volumes:

$$
\mathrm{Y}=35.794 \mathrm{X}+10
$$

where $\mathrm{Y}$ is sludge or water volume, $\mathrm{ml}$, and $\mathrm{X}$ is level, $\mathrm{cm}$, read from the graduated tape.

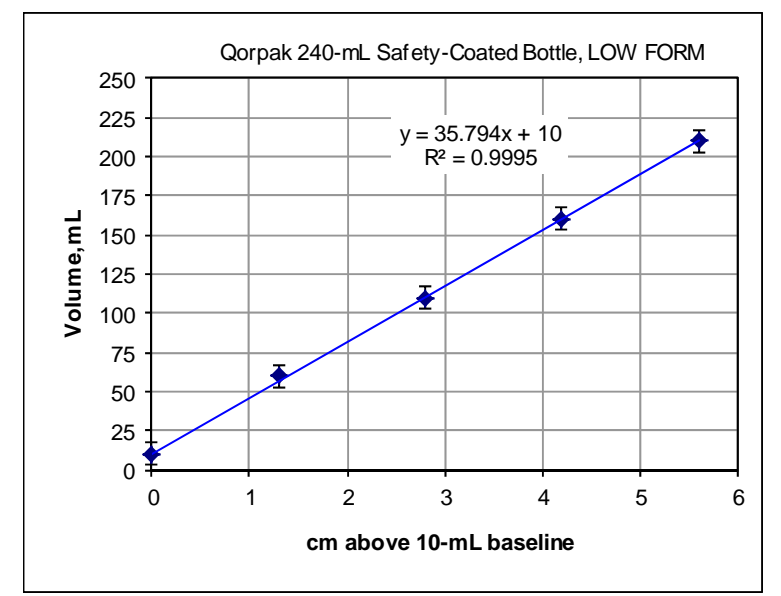

Figure 2.1. Calibration Chart for Qorpak 240-ml Jar 
Suspended and Colloidal Matter Removal from Subsamples of Supernatant. Nylon membrane filters with a $0.2-\mu \mathrm{m}$ pore size were used to produce clear supernatants for acidity and GEA measurements. The $0.5-\mathrm{ml}$ and $2.0-\mathrm{ml}$ aliquots of filtered solution were placed in separate containers for subsequent $\mathrm{pH}$ and radiometric measurements, respectively. In total, 33 pairs of samples were produced for analysis of 17 wet sludge supernatants before and after re-jarring (for the "96-13 SSOL-before" sample there was not enough liquid subsampled from the respective jar in a hot cell for filtration and analysis).

pH Measurement. An Orion 5-Star Series pH meter equipped with an Orion 9103 BN semi-micro combination electrode was used to conduct $\mathrm{pH}$ measurements. The electrode was initially calibrated with $\mathrm{pH}=4.01$ and $\mathrm{pH}=10.01$ buffer solutions. All readings at the calibration stage and $\mathrm{pH}$ measurement stage were recorded as the electrode potentials $(\mathrm{mV})$ and were converted to the $\mathrm{pH}$ scale at the data processing stage.

Gamma Energy Analysis. All 33 samples were counted as received as they were delivered to the counting room in a $2-\mathrm{ml}$ counting geometry upon receipt. The samples were measured according to the procedure RPG-CMC-450, Rev.1, "Gamma Energy Analysis (GEA) and Low-Energy Photon Spectrometry". The results were reported as $\mu \mathrm{Ci}$ per $\mathrm{ml} \pm 1 \sigma$ uncertainty for the following radionuclides: ${ }^{60} \mathrm{Co},{ }^{137} \mathrm{Cs},{ }^{152} \mathrm{Eu},{ }^{154} \mathrm{Eu},{ }^{155} \mathrm{Eu},{ }^{241} \mathrm{Am}$, and ${ }^{243} \mathrm{Cm} .{ }^{137} \mathrm{Cs}$ was the only radionuclide reported in all 33 samples. ${ }^{241} \mathrm{Am}$ was quantified in 18 samples, followed by ${ }^{154} \mathrm{Eu}$ (12 samples) and ${ }^{155} \mathrm{Eu}$ (ten samples).

Sieving of Fuel Fines Sample. The K Basin Fuel Fines sample, a dry material, was poured onto a $500-\mu \mathrm{m}$ sieve, with the minus $500-\mu \mathrm{m}$ portion collected in a receiving pan. The sieve was shaken/tapped to facilitate good separation of the minus fraction. The solids passing and the solids retained on the screen (plus $500-\mu \mathrm{m}$ ) were transferred to separate tare-weighed sample jars and reweighed to determine the masses collected. 


\subsection{Results and Discussion}

\subsection{Sieved Fractions of K Basin Fuel Fines Sample}

The K Basin Fuel Fines sample was generated during the sieving and packaging of irradiated $\mathrm{N}$ Reactor fuel coupons from spent nuclear fuel previously stored in the K Basins. At the time of generation in 2006, the mass of this sample was $188.9 \mathrm{~g}$. A description of the generation of this sample is provided in "50910/50842 Data Package for the Fuel Payload shipped for the RPL (325 Building ) to the

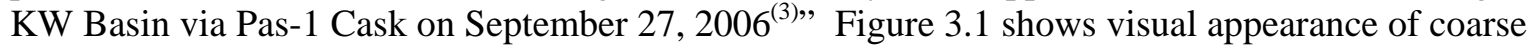
(greater than $500 \mu \mathrm{m}$ ) and fine (smaller than $500 \mu \mathrm{m}$ ) fractions of the fuel material after sieving. The total amount of material taken for sieving was $193.1 \mathrm{~g}$. Quantities of coarse and fine fractions collected after sieving were found to be $38.3 \mathrm{~g}$ and $154.2 \mathrm{~g}$ respectively. The actual amount of fuel in coarse fraction is less than $38.3 \mathrm{~g}$ because it contains several pieces of broken glass as seen in the first three photographs below. This sample will have to be cleaned up before using it in subsequent testing. Glass particles also may be present in the fine fraction but were not directly observed.

\footnotetext{
3 "Transmittal of Report 50910/50842 Fuel Palylod Date Package, "Data Package for the Fuel Payload Shipped from the RPL (325 Building ) to the KW Basin via Pas-1 Cask on September 27, 2006”, Project Letter 50842-L01, issued January 25, 2007, to Kalli R. Shupe (Fluor Hanford) by AJ Schmidt, Pacific Northwest National Laboratory, Richland Washington.
} 

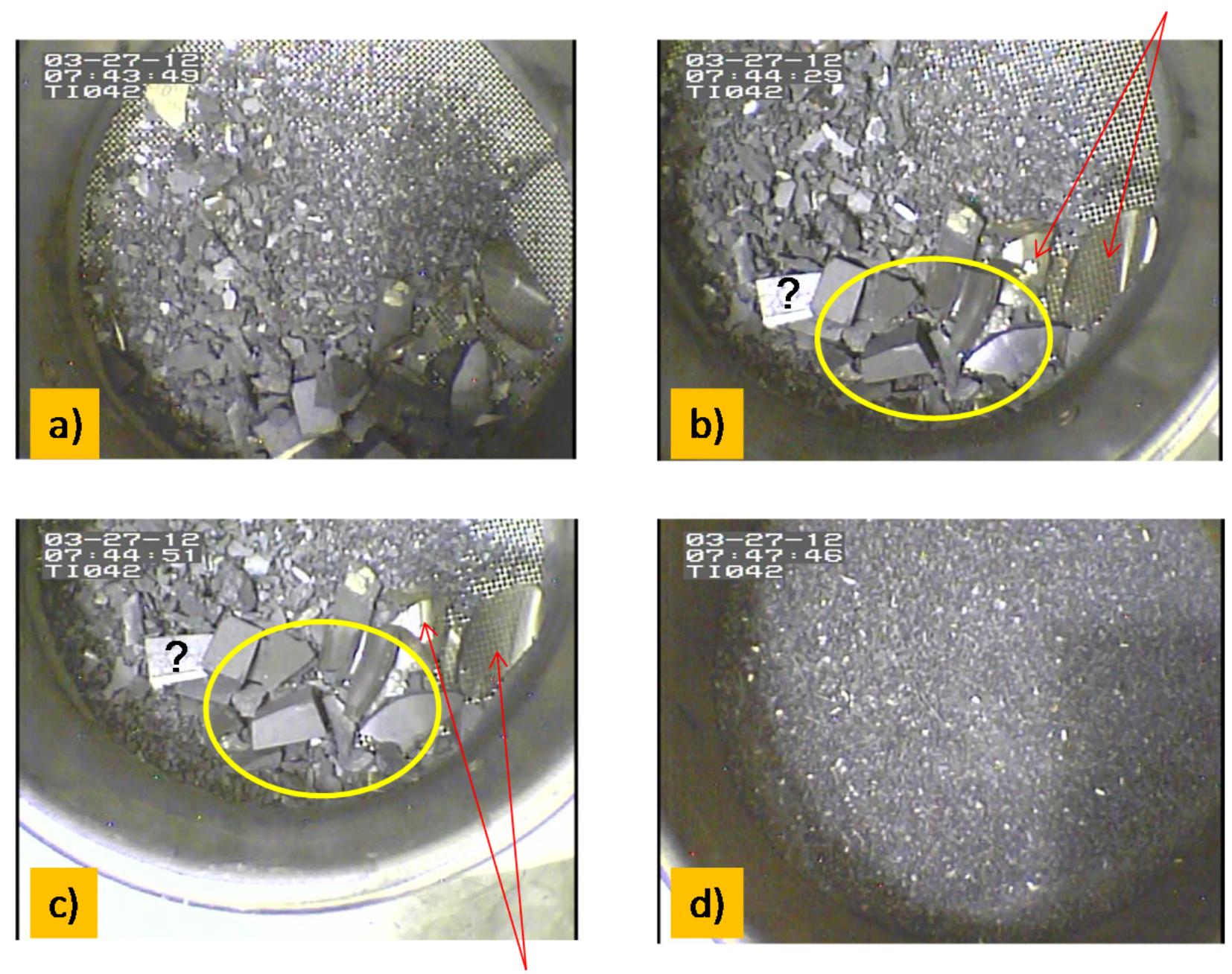

Figure 3.1. Photographs of Coarse Fraction of K Basin Fuel Material Taken from Different Angles and Distances a), b), and c); Image of Fine Fraction of K Basin Fuel Material d). In images b) and c) red arrows indicate broken glass pieces, yellow ovals show a cluster of large fuel pieces, and black question mark shows unidentified foreign material.

\subsection{Sludge Bulk Properties}

In the 2007 sample consolidation and re-jarring work (Delegard et al. 2011), representative samples were placed into calibrated centrifuge cones and used for measurement of the bulk physical properties of the sludges. In this project, the settled densities of entire sludge samples were determined by measuring the volumes and net sludge weights for the sludges packaged in new jars. Most of the volume measurements were performed after 24 hours of settling following extensive agitation to homogenize the container content and re-jarring. The results of these measurements are presented in Table 3.1 and Table 3.2 below and compared with the respective data from Delegard et al. 2011, where available. In general, the settled densities of the samples after transfer to the new container are consistent with the settled densities determined five years ago.

In the previous study (Delegard et al. 2011), the settled density was found to increase with increasing dry-basis uranium concentration in the sludge. In that study the observed trend included 13 points based on a single sample density determination (no replicates). In this work, 21 points were obtained for the 17 sludge samples measured (four sludge samples were split into two jars each, which allowed replicate 
density determinations for the same original material). With more experimental points available, it was of interest to reinvestigate the effect of uranium concentration in sludge on the settled density values. Figure 3.2 depicts the respective data.

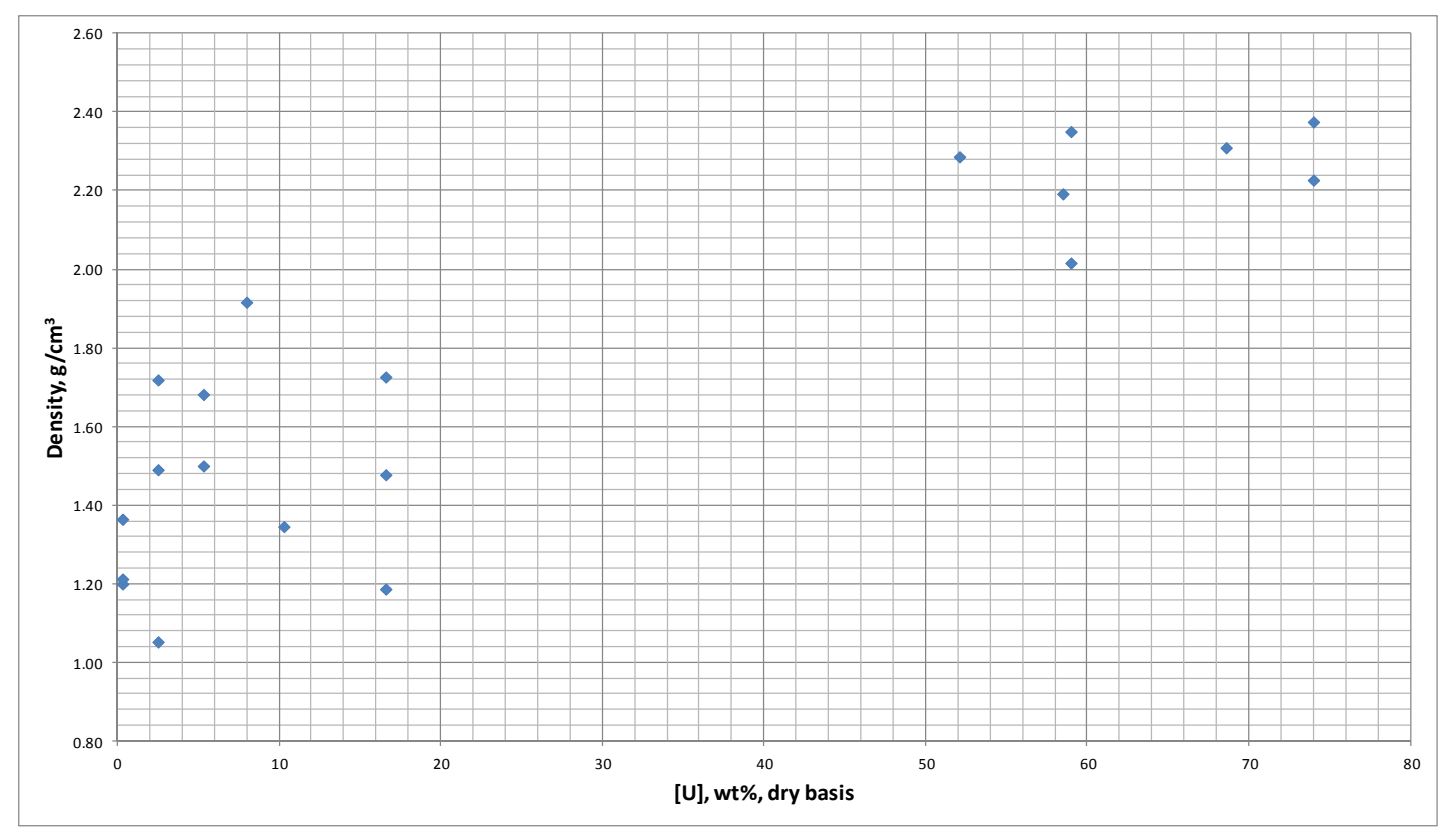

Figure 3.2. Sludge Density as a Function of Dry-Basis Uranium Concentration

It is seen that the new set of density data generally confirms the previously established trend with higher densities for the oxidized uranium-rich sludge samples. Also, as in the previous study, the samples with moderate to low uranium concentrations in sludge show significant scattering in the correlation of density to uranium concentration. The settled density values for the "FE-5 Comp 1" and "KE Pit" samples, which were found to deviate on the high side of the trend five years ago, still deviate significantly from their interpolated values based on [U] content alone. In fact, the density of both of these samples has not changed in five years (Table 3.1 and Table 3.2). The highest settled density scattering at the same [U] is observed for the three "KE NLOP" samples $\left(1.05,1.49\right.$, and $\left.1.72 \mathrm{~g} / \mathrm{cm}^{3}\right)$ and for the "KC-4-2" and "KC-4 Whole" group of samples $\left(1.48,1.19\right.$, and $\left.1.73 \mathrm{~g} / \mathrm{cm}^{3}\right)$. All three "KE NLOP" samples have significant sludge volumes in the respective jars and thus were measured with good precision. Therefore their varied settled density values reflect heterogeneity of this sludge material, which is known to be rich in rapidly settling quartz sand and also contain a much slower settling fine fraction that is, overall, low in uranium concentration (Mellinger et al. 2004; Delegard et al. 2011). In the case of "KC-4-2" sludge the density data scatter for the X-jar and Y-jar replicates is predominantly associated with uneven splitting of the original sample to produce $142 \mathrm{ml}$ and $14 \mathrm{ml}$ of the settled sludge, respectively. The X-jar value of $1.48 \mathrm{~g} / \mathrm{cm}^{3}$ is in a reasonable agreement with the $1.60 \mathrm{~g} / \mathrm{cm}^{3}$ value determined five years ago. The $1.72 \mathrm{~g} / \mathrm{cm}^{3}$ value for the "KC-4 Whole" measured in this study is also in satisfactory agreement with the $1.60 \mathrm{~g} / \mathrm{cm}^{3}$ value for this sample determined previously.

Additional volume measurements for all the wet samples were performed approximately three months after the re-jarring when the final inspection of the samples was conducted before their placement in the rectangular storage bins for a long-term storage in a hot cell \#5. These results also are shown in Tables 3.1 and 3.2. However, the latest round of volume determinations was not accompanied by weighing the jars to account for potential water evaporation effect. On the other hand, this effect can be quantified by comparing levels of supernatant water before and after the three-month storage time in the respective samples. Calculated densities for the well-settled samples, along with relative density changes in the process of undisturbed sample storage, are also added to the tables. 
Table 3.1. Settled Sludge Data and Calculated Densities for the First Seven Wet Samples Listed in Table 1.1

\begin{tabular}{|c|c|c|c|c|c|c|c|c|c|c|}
\hline & $\begin{array}{l}\mathrm{KC}-2 / 3 \\
\text { Comp X }\end{array}$ & $\begin{array}{l}\mathrm{KC}-2 / 3 \\
\text { Comp Y }\end{array}$ & $96-05$ & $\begin{array}{c}\text { 96-13 Comp } \\
\text { A }\end{array}$ & $\begin{array}{l}\text { KE NLOP } \\
\# 2\end{array}$ & KC-4-2 X & KC-4-2 Y & $\mathrm{KC}-6$ & $\begin{array}{c}\text { FE-5 Comp } \\
1 \mathrm{X}\end{array}$ & $\begin{array}{c}\text { FE-5 Comp1 } \\
\text { Y }\end{array}$ \\
\hline Jar tare, $\mathrm{g}$ & 236.7 & 236.2 & 235.1 & 236.2 & 234.9 & 248.4 & 235.5 & 236 & 236.9 & 237 \\
\hline Gross sludge $\& \mathrm{H}_{2} \mathrm{O}, \mathrm{g}$ & 649.8 & 713.6 & 569.9 & 619.6 & 564.7 & 534 & 323.2 & 483.5 & 573.4 & 354 \\
\hline Settled sludge level, $\mathrm{cm}^{(\mathrm{a})}$ & $4.9(4.5)$ & $4.8(4.7)$ & $2.3(2.3)$ & $3.4(3.4)$ & $5.3(5.0)$ & $3.7(3.3)$ & $0.1(0.0)$ & $2.9(3.4)$ & $4.3(4.2)$ & $1.1(0.9)$ \\
\hline Settled sludge volume, $\mathrm{ml}$ & 185.4 & 181.8 & 92.3 & 131.7 & 199.7 & 142.4 & 13.6 & 113.8 & 163.9 & 49.4 \\
\hline Sludge \& $\mathrm{H}_{2} \mathrm{O}$ level, $\mathrm{cm}^{(\mathrm{a})}$ & $6.0(6.0)$ & $6.2(6.2)$ & $6.0(5.9)$ & $5.8(5.7)$ & $6.2(6.5)$ & $5.8(5.8)$ & $2.1(1.9)$ & $6.0(5.8)$ & $6.0(5.7)$ & $2.3(2.3)$ \\
\hline Sludge $\& \mathrm{H}_{2} \mathrm{O}$ volume, $\mathrm{ml}$ & 224.8 & 231.9 & 224.8 & 214.0 & 231.9 & 217.6 & 85.2 & 224.8 & 224.8 & 92.3 \\
\hline $\begin{array}{l}\text { Sludge \& } \mathrm{H}_{2} \mathrm{O} \text { net weight, } \\
\mathrm{g}\end{array}$ & 413.1 & 477.4 & 334.8 & 383.4 & 329.8 & 285.6 & 87.7 & 247.5 & 336.5 & 117 \\
\hline Water volume, $\mathrm{ml}$ & 39.4 & 50.1 & 132.4 & 82.3 & 32.2 & 75.2 & 71.6 & 111.0 & 60.8 & 43.0 \\
\hline Settled sludge weight, $g$ & 373.7 & 427.3 & 202.4 & 301.1 & 297.6 & 210.4 & 16.1 & 136.5 & 275.7 & 74.0 \\
\hline $\begin{array}{l}\text { Settled sludge density, } \\
\mathrm{g} / \mathrm{cm}^{3}\end{array}$ & 2.02 & 2.35 & 2.19 & 2.29 & 1.49 & 1.48 & 1.19 & 1.20 & 1.68 & 1.50 \\
\hline $\begin{array}{l}\text { Settled sludge density, } \\
\mathrm{g} / \mathrm{cm}^{3} \text { remeasured } 12 \\
\text { weeks after re-jarring }\end{array}$ & 2.10 & 2.38 & 2.19 & 2.29 & 1.52 & 1.53 & 1.25 & 1.17 & 1.70 & 1.58 \\
\hline $\begin{array}{l}\text { Density change with time, } \\
\%\end{array}$ & 4.2 & 1.2 & 0.0 & 0.0 & 1.9 & 3.6 & 5.6 & -2.3 & 0.9 & 5.7 \\
\hline $\begin{array}{l}\text { Delegard et al. } 2011 \text { data, } \\
\mathrm{g} / \mathrm{cm}^{3}\end{array}$ & \multicolumn{2}{|c|}{2.14} & 1.77 (cone) & $\begin{array}{l}2.46 \\
{\left[1997^{(\mathrm{b})}\right]}\end{array}$ & 1.06 (cone) & \multicolumn{2}{|c|}{1.53 (cone); 1.60 (jar) } & $\begin{array}{r}1.31 \text { (cone); } \\
1.20 \text { (jar) }\end{array}$ & \multicolumn{2}{|c|}{1.66 (cone); 1.68 (jar) } \\
\hline U conc in sludge, $\mathrm{wt} \%$ & 59 & 59 & 58.5 & 52.1 & 2.51 & 16.60 & 16.60 & 0.31 & 5.32 & 5.32 \\
\hline
\end{tabular}

(a) The numbers in parentheses are sludge and water levels determined 12 weeks after re-jarring. These numbers were also used for the settled sludge density calculations as shown in the $4^{\text {th }}$ row from the bottom.

(b) Makenas BJ, TL Welsh, RB Baker, EW Hoppe, AJ Schmidt, J Abrefah, JM Tingey, PR Bredt, and GR Golcar. 1997. Analysis of Sludge from Hanford K East Basin Canisters. HNF-SP-1201, DE\&S Hanford, Inc., Richland, WA. 
Table 3.2. Settled Sludge Data and Calculated Densities for the Last Ten Wet Samples Listed in Table 1.1

\begin{tabular}{|c|c|c|c|c|c|c|c|c|c|c|c|}
\hline & $\begin{array}{l}\text { KE Floc } \\
\text { Comp }\end{array}$ & $\begin{array}{c}96-13 \\
\text { Solids Grad }\end{array}$ & $\begin{array}{l}96-13 \\
\text { SSOL }\end{array}$ & KC-4 Whole & KE Pit & $\begin{array}{c}\text { KE NLOP } \\
\# 1\end{array}$ & $\begin{array}{l}\text { KE NLOP } \\
\quad \# 3\end{array}$ & KC-4 P250 & KC-1 M500 & $\begin{array}{c}\text { KC-6 } \\
\text { New X }\end{array}$ & $\begin{array}{l}\text { KC-6 } \\
\text { New Y }\end{array}$ \\
\hline Jar tare, $g$ & 235.3 & 237.6 & 237.1318 & 236.3 & 235.3 & 254.1 & 238.1 & 236.8 & 237.6 & 236.9385 & 234.9453 \\
\hline $\begin{array}{l}\text { Gross sludge \& } \mathrm{H}_{2} \mathrm{O} \text {, } \\
\text { g }\end{array}$ & 498.4 & 473.3 & 626.4 & 489.7 & 532.7 & 486.3 & 596.4 & 413.4 & 335.6 & 468.7 & 459.5 \\
\hline $\begin{array}{l}\text { Settled sludge level, } \\
\mathrm{cm}^{\text {(a) }}\end{array}$ & $3.4(2.6)$ & $1.6(1.6)$ & $3.5(3.5)$ & $2.2(2.2)$ & $2.7(2.5)$ & $3.7(2.7)$ & $5.4(5.0)$ & $1.2(0.7)$ & $<0^{\text {(b) }}(0.3)$ & $3.0(3.0)$ & $3.0(3.0)$ \\
\hline $\begin{array}{l}\text { Settled sludge } \\
\text { volume, } \mathrm{ml}\end{array}$ & 131.7 & 67.3 & 135.3 & 88.8 & 106.6 & 142.4 & 203.3 & 53.0 & $20.7^{(\mathrm{c})}$ & 117.4 & 117.4 \\
\hline $\begin{array}{l}\text { Sludge \& } \mathrm{H}_{2} \mathrm{O} \text { level, } \\
\mathrm{cm}^{\text {(a) }}\end{array}$ & $5.8(5.6)$ & $4.0(3.8)$ & $5.4(5.4)$ & $5.0(4.8)$ & $5.3(5.0)$ & $6.0(5.8)$ & $5.65(6.0)$ & $3.9(3.4)$ & $1.7(1.7)$ & $5.5(5.5)$ & $4.8(5.4)$ \\
\hline $\begin{array}{l}\text { Sludge \& } \mathrm{H}_{2} \mathrm{O} \\
\text { volume, } \mathrm{ml}\end{array}$ & 217.6 & 153.2 & 203.3 & 189.0 & 199.7 & 224.8 & 212.2 & 149.6 & 70.8 & 206.9 & 181.8 \\
\hline $\begin{array}{l}\text { Sludge \& } \mathrm{H}_{2} \mathrm{O} \text { net } \\
\text { weight, } \mathrm{g}\end{array}$ & 263.1 & 235.7 & 389.3 & 253.4 & 297.4 & 232.2 & 358.3 & 176.6 & 98.0 & 231.8 & 224.6 \\
\hline Water volume, $\mathrm{ml}$ & 85.9 & 85.9 & 68.0 & 100.2 & 93.1 & 82.3 & 8.9 & 96.6 & 50.1 & 89.5 & 64.4 \\
\hline $\begin{array}{l}\text { Settled sludge weight, } \\
\mathrm{g}\end{array}$ & 177.2 & 149.8 & 321.3 & 153.2 & 204.3 & 149.9 & 349.4 & 80.0 & 47.9 & 142.3 & 160.1 \\
\hline $\begin{array}{l}\text { Settled sludge } \\
\text { density, } \mathrm{g} / \mathrm{cm}^{3}\end{array}$ & 1.35 & 2.23 & 2.37 & 1.73 & 1.92 & 1.05 & 1.72 & 1.51 & - & 1.21 & 1.36 \\
\hline $\begin{array}{l}\text { Settled sludge } \\
\text { density, } \mathrm{g} / \mathrm{cm}^{3} \\
\text { remeasured } 12 \text { weeks } \\
\text { after re-jarring }\end{array}$ & 1.44 & 2.23 & 2.37 & 1.73 & 1.98 & 1.07 & 1.77 & 1.77 & 2.31 & 1.21 & 1.36 \\
\hline $\begin{array}{l}\text { Density change with } \\
\text { time, } \%\end{array}$ & 7.1 & 0.0 & 0.0 & 0.0 & 3.4 & 1.7 & 3.2 & 17.2 & - & 0.0 & 0.0 \\
\hline $\begin{array}{l}\text { Delegard et al. } 2011 \\
\text { data }\end{array}$ & $\begin{array}{r}1.25 \text { (cone); } \\
1.30(\mathrm{jar})\end{array}$ & no data & no data & $\begin{array}{r}1.60 \text { (cone); } \\
1.56(\mathrm{jar}) \\
\end{array}$ & $\begin{array}{r}1.77 \text { (cone); } \\
1.92 \text { (jar) } \\
\end{array}$ & \multicolumn{2}{|c|}{1.06 (cone) } & no data & $\begin{array}{r}2.05 \text { (cone); } \\
2.66 \text { (jar) }\end{array}$ & \multicolumn{2}{|c|}{$\begin{array}{c}\text { No data for KC-6 } \\
\text { Carboy }\end{array}$} \\
\hline $\begin{array}{l}\text { U conc. in sludge, } \\
\mathrm{wt} \%\end{array}$ & 10.30 & 74.00 & 74.00 & 16.60 & 7.99 & 2.51 & 2.51 & no data & 68.60 & 0.31 & 0.31 \\
\hline
\end{tabular}

(a) The numbers in parentheses are sludge and water levels determined 12 weeks after re-jarring. These numbers were also used for the settled sludge density calculations as shown in the $4^{\text {th }}$ row from the bottom.

(b) The sludge level for this sample was found to be below the $10-\mathrm{ml}(0.0 \mathrm{~cm})$ graduation mark. Exact settled sludge volume cannot be determined.

(c) Calculated based on sludge level measured 12 weeks after re-jarring. 


\subsection{Sample pH}

The $\mathrm{pH}$ values of the 17 wet sludge supernatants were determined using a calibrated $\mathrm{pH}$ electrode before and after re-jarring. For technical reasons it was not possible to produce sufficient amounts of supernatant of the "96-13 SSOL" sample before re-jarring. The results are presented below in Table 3.3.

Table 3.3. Acidity of KE Basin Sludge Supernatants Before and After Re-Jarring

\begin{tabular}{|c|c|c|c|}
\hline Sample ID & pH Before Re-Jarring & pH After Re-Jarring & Delegard et al. 2011 Data \\
\hline KC-2/3 & 5.53 & 5.43 & 5.47 \\
\hline 96-05 & 5.52 & 4.73 & 4.89 \\
\hline 96-13 KE Comp A & 5.47 & 4.97 & 4.71 \\
\hline KE NLOP\#2 & 8.28 & 8.21 & - \\
\hline KC-4-2 & 7.84 & 7.76 & 8.66 \\
\hline KC-6 & 8.43 & 8.49 & 8.09 \\
\hline FE-5 Comp 1 & 8.18 & 8.18 & 7.26 \\
\hline KE Floc Comp & 7.49 & 7.52 & - \\
\hline 96-13 Solids Grad & 5.19 & 5.25 & - \\
\hline 96-13 SSOL & no sample & 5.12 & 3.47 \\
\hline KC-4 Whole & 4.11 & 4.06 & 7.79 \\
\hline KE Pit & 7.62 & 7.81 & 7.82 \\
\hline KE NLOP\#1 & 8.33 & 8.25 & 7.75 \\
\hline KE NLOP\#3 & 8.49 & 8.41 & - \\
\hline KC-6 New & 8.80 & 8.75 & - \\
\hline KC-1 M500 & 7.81 & 7.86 & 4.68 \\
\hline
\end{tabular}

The data presented in Table 3.3 are discussed in detail in the context of ${ }^{137} \mathrm{Cs}$ and ${ }^{241} \mathrm{Am}$ activity levels in the filtered supernatants, as well as uranium concentration in sludge in the following section.

\subsection{Fission Products and Transplutonium Metals Activity Levels in Sludge Supernatants Before and After Re-Jarring}

The list of gamma emitters detected and quantified in the sludge supernates submitted for gamma energy analysis included ${ }^{60} \mathrm{Co},{ }^{137} \mathrm{Cs},{ }^{152} \mathrm{Eu},{ }^{154} \mathrm{Eu},{ }^{155} \mathrm{Eu},{ }^{241} \mathrm{Am}$, and ${ }^{243} \mathrm{Cm}$. ${ }^{137} \mathrm{Cs}$ was the only radionuclide reported in all 33 samples. ${ }^{241} \mathrm{Am}$ was quantified in 18 samples, followed by ${ }^{154} \mathrm{Eu}$ (12 samples) and ${ }^{155} \mathrm{Eu}$ (ten samples). The data for ${ }^{137} \mathrm{Cs}$ and ${ }^{241} \mathrm{Am}$ activity levels in the sludge supernatants are summarized in Table 3.4. ${ }^{137} \mathrm{Cs}$ activity levels before and after re-jarring for the same sludge samples were similar to each other ( $<20 \%$ difference), with two notable exceptions: for the "96-05" and "96-13 KE Comp A" sludges, re-jarring resulted in 11.5- and 8.1-fold increases, respectively, in levels of soluble radiocesium. Repeated counting of these samples confirmed the observed differences. An assumption was made initially that the supernatants collected after re-jarring had become contaminated with some foreign ${ }^{137} \mathrm{Cs}$-rich water soluble material present in the hot cell environment. However, Table 3.3 data above indicate that such significant Cs activity level differences were accompanied by the most significant $\mathrm{pH}$ changes for the same couples of samples compared with other samples. This observation gives evidence that at least some of the examined sludges, while in storage, gradually developed areas of increased acidity in the sludge pores filled with interstitial water, possibly as a result of water radiolysis or ion exchange between $\mathrm{M}^{+}$or $\mathrm{M}^{2+}$ metal cations in the aqueous phase and proton-exchangeable sites on the surface of metaschoepite and other U(VI) phases. In the process of re-jarring, interstitial water becomes well mixed with the bulk water present as a relatively thick layer above the settled sludge and both acidity and ${ }^{137} \mathrm{Cs}$ activity levels might increase significantly after homogenization. 
Table 3.4. ${ }^{137} \mathrm{Cs}$ and ${ }^{241} \mathrm{Am}$ Concentrations in Filtered Sludge Supernatants Before and After Re-Jarring

\begin{tabular}{|c|c|c|c|c|}
\hline \multirow[b]{2}{*}{ Sample ID } & \multicolumn{2}{|c|}{$\left[{ }^{137} \mathrm{Cs}\right], \mu \mathrm{Ci} / \mathrm{ml} \pm 1$ sigma uncertainty } & \multicolumn{2}{|c|}{$\left[{ }^{241} \mathrm{Am}\right], \mu \mathrm{Ci} / \mathrm{ml} \pm$ 1sigma uncertainty } \\
\hline & $\begin{array}{l}\text { Before Re- } \\
\text { Jarring }\end{array}$ & After Re-Jarring & Before Re-Jarring & After Re-Jarring \\
\hline KC 2/3 Comp & $1.22 \mathrm{e}-2 \pm 2 \%$ & $8.58 \mathrm{e}-3 \pm 2 \%$ & $3.89 \mathrm{e}-2 \pm 2 \%$ & $1.82 \mathrm{e}-3 \pm 5 \%$ \\
\hline $96-05$ & $8.30 \mathrm{e}-3 \pm 2 \%$ & $9.58 \mathrm{e}-2 \pm 2 \%$ & $5.58 \mathrm{e}-4 \pm 4 \%$ & $1.03 e-3 \pm 4 \%$ \\
\hline 96-13 Comp A & $4.93 e-3 \pm 2 \%$ & $3.99 e-2 \pm 2 \%$ & $5.26 \mathrm{e}-4 \pm 2 \%$ & No data \\
\hline KE NLOP \#1 & $1.64 \mathrm{e}-1 \pm 2 \%$ & $1.41 \mathrm{e}-1 \pm 2 \%$ & No data & No data \\
\hline KE NLOP \#2 & $1.20 \mathrm{e}-1 \pm 2 \%$ & $1.08 \mathrm{e}-1 \pm 2 \%$ & $6.59 \mathrm{e}-4 \pm 5 \%$ & $6.20 \mathrm{e}-4 \pm 9 \%$ \\
\hline KE NLOP \#3 & $1.60 \mathrm{e}-1 \pm 2 \%$ & $1.15 \mathrm{e}-1 \pm 2 \%$ & $6.00 \mathrm{e}-4 \pm 14 \%$ & $4.68 \mathrm{e}-4 \pm 18 \%$ \\
\hline KC-4-2 & $3.30 \mathrm{e}+0 \pm 2 \%$ & $2.70 \mathrm{e}+0 \pm 2 \%$ & No data & No data \\
\hline FE-5 Comp 1 & $1.53 \mathrm{e}-1 \pm 2 \%$ & $1.50 \mathrm{e}-1 \pm 2 \%$ & No data & No data \\
\hline KE Floc Comp & $8.49 \mathrm{e}-1 \pm 2 \%$ & $(5.79 \mathrm{e}-1) \times 1.25^{\mathrm{a}} \pm 2 \%$ & No data & No data \\
\hline 96-13 Solids Grad & $3.89 \mathrm{e}-2 \pm 2 \%$ & $3.18 \mathrm{e}-2 \pm 2 \%$ & $7.58 \mathrm{e}-2 \pm 2 \%$ & $4.91 \mathrm{e}-2 \pm 2 \%$ \\
\hline 96-13 SSOL & $\begin{array}{l}\text { Insufficient } \\
\text { sample for } \\
\text { analysis }\end{array}$ & $6.04 \mathrm{e}-2 \pm 2 \%$ & $\begin{array}{l}\text { Insufficient sample } \\
\text { for analysis }\end{array}$ & $4.26 \mathrm{e}-2 \pm 2 \%$ \\
\hline KC-4 Whole & $3.22 \mathrm{e}+0 \pm 2 \%$ & $\begin{array}{l}(3.76 \mathrm{e}-1) \times 10.0^{\mathrm{b}} \pm \\
2 \%\end{array}$ & $6.98 e+0 \pm 2 \%$ & $(7.88 \mathrm{e}-1) \times 10.0 \pm 2 \%$ \\
\hline KE Pit & $1.36 \mathrm{e}-1 \pm 2 \%$ & $8.61 \mathrm{e}-2 \pm 2 \%$ & No data & No data \\
\hline KC-4 P250 & $3.53 e+0 \pm 2 \%$ & $1.87 \mathrm{e}+0 \pm 2 \%$ & No data & No data \\
\hline KC-1 M500 & $1.77 \mathrm{e}-2 \pm 2 \%$ & $2.00 \mathrm{e}-2 \pm 2 \%$ & $1.70 \mathrm{e}-3 \pm 2 \%$ & $1.26 \mathrm{e}-3 \pm 2 \%$ \\
\hline KC-6 & $4.76 \mathrm{e}-2 \pm 2 \%$ & $4.87 \mathrm{e}-2 \pm 2 \%$ & $6.63 e-4 \pm 11 \%$ & $1.95 e-4 \pm 46 \%$ \\
\hline KC-6 New & $2.25 \mathrm{e}-2 \pm 2 \%$ & $2.45 \mathrm{e}-2 \pm 2 \%$ & No data & No data \\
\hline
\end{tabular}

a) $1.6 \mathrm{ml}$ of “KE Floc Comp_After Re-Jarring” filtrate was mixed with $0.4 \mathrm{ml}$ of DI $\mathrm{H}_{2} \mathrm{O}$ to produce $2.0 \mathrm{ml}$ aliquote required for GEA measurement. This dilution was applied for GEA sample only. No dilution was applied to "KE Floc Comp_After Re-Jarring” filtrate used for pH measurement.

b) Due to extreme difficulty in filtration of "KC-4 Whole_After Re-Jarring” to produce $2 \mathrm{ml}$ of filtered product, the GEA sample was prepared by mixing $0.2 \mathrm{ml}$ of the filtrate with $1.8 \mathrm{ml}$ of $\mathrm{DI}_{2} \mathrm{O}$. No dilution was applied to "KC-4 Whole_After Re-Jarring” filtrate used for pH measurement.

In this regard it was of interest to compare ${ }^{137} \mathrm{Cs}$ activity levels and acidity of the respective samples for all 33 sludge supernatant samples. Figure 3.3 below shows the relevant data. One can clearly see that for the seven sludge samples showing $\mathrm{pH}$ range from 4.01 to 5.52 there is a strong correlation between $\mathrm{pH}$ and ${ }^{137}$ Cs level. Both "96-05" and "96-13 KE Comp A" points (highlighted in yellow and pink, respectively) nicely fit this trend, which discounts, but does not eliminate, the possibility that the supernatants were contaminated. 


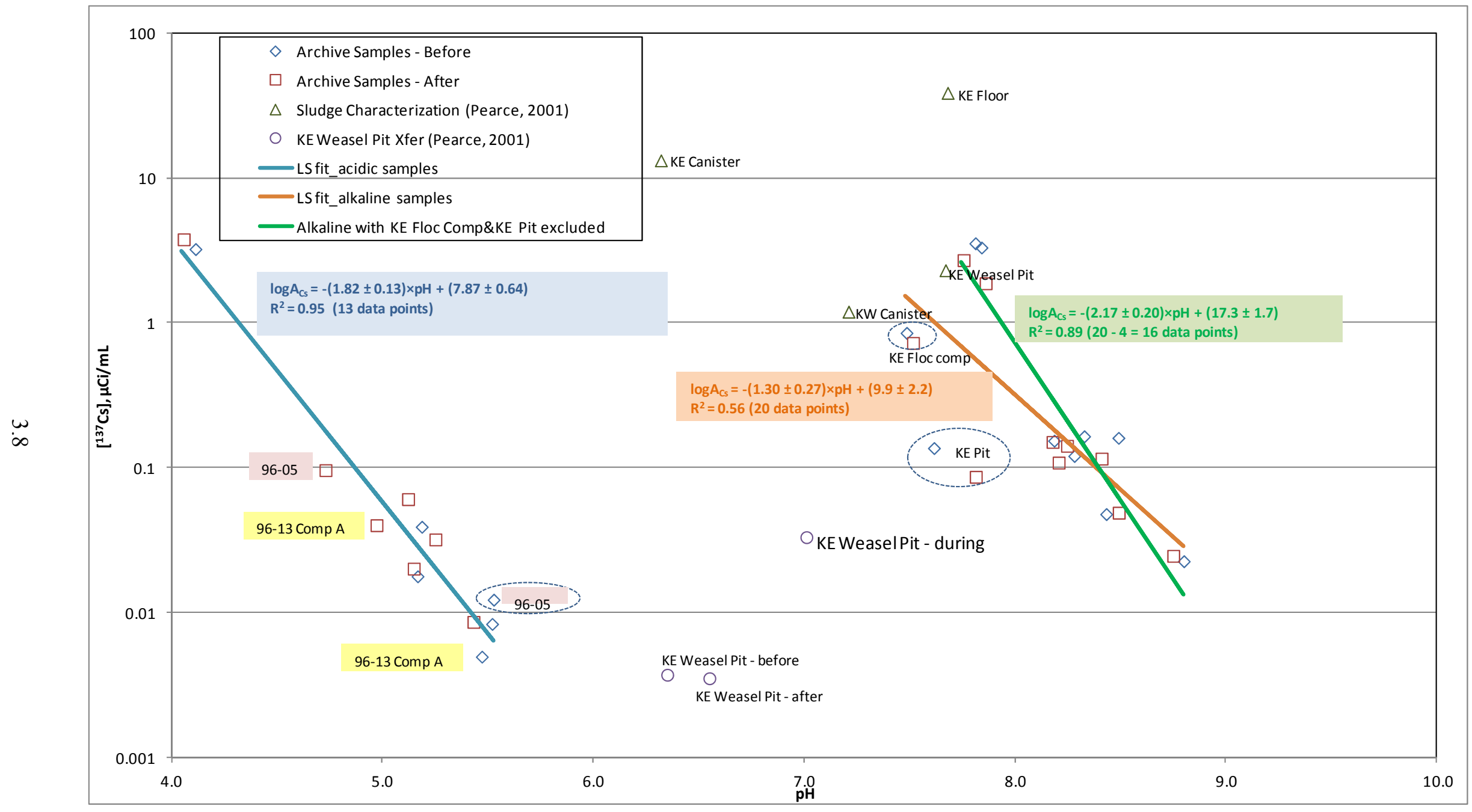

Figure 3.3. $\quad{ }^{137}$ Cs Activity Levels in Filtered Sludge Supernatants Before and After Re-Jarring as a Function of pH. Data on the radiocesium values for the "Before," "During," and "After" transfers of KE Basin sludge to the KE Weasel Pit are from Table 4-2 in HNF-SD-SNF-TI-009 (Pearce 2001, while the concentrations in the characterization of the K Basin waters are from Table 4-1 in HNF-SD-SNF-TI-009; Pearce 2001). Note: this figure does not include data obtained in recent settling tests on Engineered Containerized sludge (see Table 3.5 and preceding text for more information). 
The ten remaining sludge supernatants form a group of near-neutral to mildly alkaline samples $(\mathrm{pH}$ range from 7.4 to 8.5). It appears that for this group of samples, elevation of $\mathrm{pH}$ decreases ${ }^{137} \mathrm{Cs}$ activity levels, although correlation coefficient for the linear regression applied to all 20 points (orange line) is much poorer than for the weakly acidic cluster of points (blue line). Exclusion of two obvious outliers ("KE Floc Comp" and "KE Pit") from linear regression analysis improves the correlation coefficient and illustrates this dependence more clearly (green line and respective legend).

From the practical point of view, it is seen that the ${ }^{137} \mathrm{Cs}$ concentration values given in the sludge characterization reports bracket the values obtained in the recent sampling of the archive sludges. The radiocesium values for the "Before," "During," and "After" transfers of KE Basin sludge to the KE Weasel Pit (from Table 4-2 in HNF-SD-SNF-TI-009; Pearce 2001) are at the low end of those observed in this round of archive sludge measurements, while the concentrations in the characterization of the K Basin waters (data from Table 4-1 in HNF-SD-SNF-TI-009; Pearce 2001) are at the high end of those observed in the archive sludge.

It appears that the ${ }^{137} \mathrm{Cs}$ concentrations in the aged sludge supernatants are not appreciably higher than those reported in the prior sludge characterizations. Therefore, no evidence for leaching or displacement of ${ }^{137} \mathrm{Cs}$ from the sludge solids to the supernatant solution can be seen with aging.

Table 3.5 below shows $\mathrm{pH}$ and $\left[{ }^{137} \mathrm{Cs}\right]$ activity levels from Engineered Container Sludge Settling Tests performed in the period from March 2010 until June 2012. As follows from the presented data, the concentrations of ${ }^{137} \mathrm{Cs}$ in $\mathrm{KW}-220,-240,-250$ and -260 supernatants range from 0.00965 to $0.0327 \mu \mathrm{Ci} / \mathrm{ml}$ with $\mathrm{pH}$ variation from 7.39 to 7.73 without any clear functional dependence between these two parameters. For the KW-230 supernatants, it appears that radiocesium activity level is decreasing from 0.725 to $0.449 \mu \mathrm{Ci} / \mathrm{ml}$ with $\mathrm{pH}$ elevation from 6.34 to 6.62 , but this conclusion is based on three experimental points only. For KW210 supernatants (six samples listed in the bottom section of Table 3.5) no $\left[{ }^{137} \mathrm{Cs}\right]$ vs $\mathrm{pH}$ relationship could be established due to lack of $\mathrm{pH}$ data.

Among all archived sludge samples examined in this report, only two samples have similar acidity to those listed in Table 3.5 from the Engineered Container Sludge Settling Tests: "KE Floc Comp_Before" showed $\mathrm{pH} 7.49$ with $\left[{ }^{137} \mathrm{Cs}\right]=0.850 \mu \mathrm{Ci} / \mathrm{ml}$ and "KE Pit_Before" measured $\mathrm{pH}$ was 7.62 with $\left[{ }^{137} \mathrm{Cs}\right]=0.136 \mu \mathrm{Ci} / \mathrm{ml}$. After re-jarring, these numbers changed to $\mathrm{pH} 7.52$ and $\left[{ }^{137} \mathrm{Cs}\right]=0.725 \mu \mathrm{Ci} / \mathrm{ml}$ for "KE Floc Comp" and to $\mathrm{pH}=7.81$ and $\left[{ }^{137} \mathrm{Cs}\right]=0.0861 \mu \mathrm{Ci} / \mathrm{ml}$ for "KE Pit".

Comparison of the engineered container sludge settling test results with the re-jarring results in terms of Cs activity levels should be done with caution, as the settling tests were conducted with much more dilute aqueous suspensions of sludge compared with the re-jarred samples, most of which had sludge volumes exceeding water layer volumes above the sludge. 
Table 3.5. Acidity and ${ }^{137} \mathrm{Cs}$ Concentrations in Filtrates of Engineered Containerized Sludge Samples Used in Settling Tests

\begin{tabular}{|c|c|c|}
\hline Sample ID & $\mathrm{pH}$ & {$\left[{ }^{137} \mathrm{Cs}\right], \mu \mathrm{Ci} / \mathrm{ml}$} \\
\hline \multicolumn{3}{|c|}{ PNNL-19213 (Fiskum et al. 2010 Stage 1 and Stage 2 Settling Studies of K-Basin Containerized Sludge) } \\
\hline SSKW240 & 7.73 & $1.31 \mathrm{E}-2$ \\
\hline SSKW250 & 7.41 & $1.37 \mathrm{E}-2$ \\
\hline SSKW260 & 7.62 & $1.02 \mathrm{E}-2$ \\
\hline SSKW260R & 7.72 & $0.965 \mathrm{E}-2$ \\
\hline SSKW220A1 & 7.39 & $2.20 \mathrm{E}-2$ \\
\hline SSKW220A3 & 7.46 & $3.27 \mathrm{E}-2$ \\
\hline SSKW220B3 & 7.50 & $2.88 \mathrm{E}-2$ \\
\hline SSKW220B3R & 7.63 & $2.28 \mathrm{E}-2$ \\
\hline \multicolumn{3}{|c|}{$\begin{array}{l}\text { PNNL-20884 (Billing et al. } 2011 \text { Settling Studies of KW Basin Settler Sludge from SCS-CON-230 and Settler Sludge } \\
\text { Simulant (230)) }\end{array}$} \\
\hline SSKW230-05S-FP & 6.62 & $4.49 \mathrm{E}-1$ \\
\hline SSKW230-05D-FP & 6.56 & $4.79 \mathrm{E}-1$ \\
\hline SSKW230-10S-FP & 6.34 & $7.25 \mathrm{E}-1$ \\
\hline \multicolumn{3}{|c|}{$\begin{array}{c}\text { PNNL-21447 (Fiskum et al. } 2012 \text { Integrated Report for the Further Evaluation of Total Organic Carbon, Particle } \\
\text { Size Distribution, and Gel Formation in Selected Samples of K Basin Sludge; data from Section 4.4.3”Filtration } \\
\text { Testing Results") }\end{array}$} \\
\hline $\begin{array}{l}\text { KW210 Feed }(0.5-w t \% \text { test }) \text {, } \\
\text { TI049-05F-G-A1 }\end{array}$ & - & $7.83 \mathrm{E}-2$ \\
\hline $\begin{array}{l}\text { KW210 Feed duplicate, } \\
\text { TI049-05F-G-A2 }\end{array}$ & - & $8.05 \mathrm{E}-2$ \\
\hline $\begin{array}{l}\text { KW210 Filtrate }(0.5-w t \%) \\
\text { TI049-05F-G-B }\end{array}$ & - & $6.53 \mathrm{E}-2$ \\
\hline $\begin{array}{l}\text { KW210 Feed (2.0-wt\% test), } \\
\text { TI049-20F-G-A1 }\end{array}$ & - & $9.04 \mathrm{E}-2$ \\
\hline $\begin{array}{l}\text { KW210 Feed duplicate, } \\
\text { TI049-20F-G-A2 }\end{array}$ & - & $9.47 \mathrm{E}-2$ \\
\hline $\begin{array}{l}\text { KW210 Filtrate (2.0-wt\%), TI049- } \\
\text { 20F-G-B }\end{array}$ & - & $8.39 \mathrm{E}-2$ \\
\hline
\end{tabular}

Figure 3.4 presents $\mathrm{pH}$ dependence of ${ }^{241} \mathrm{Am}$ activity levels in sludge supernatants. There are only 18 points available for analysis, with 12 points represented by acidic supernatants and six points clustered in a weakly alkaline region. The weakly acidic region of the plot demonstrates a similar behavior to the ${ }^{137} \mathrm{Cs}$ trend, with the highest levels of soluble Am observed for the most acidic sample ("KC-4 Whole"), while the samples with the highest $\mathrm{pH}$ in this group of points ("96-05 before" and "96-13 KE Comp A before") have the lowest concentration of Am. Interestingly, this steep drop of Am concentration from $\mathrm{pH}=4.1$ to $\mathrm{pH}=5.5$ (4.2 log units of $[\mathrm{Am}])$ corresponds to $\mathrm{pH}$ change of $5.5-4.1=1.4$ or $1.4 \log$ units decrease in $\mathrm{H}^{+}$concentration. The ratio of these two numbers, $4.2 / 1.4=3.0$, indicates that $\mathrm{Am}$ concentration in these samples could be governed either by solubility of $\operatorname{Am}(\mathrm{OH})_{3}$ or by competition between $\mathrm{H}^{+}$and $\mathrm{Am}^{3+}$ cations for sorption sites in the process of their uptake by solid-phase constituent(s) of the sludge. The fact that Am concentrations found in this group of samples are several orders of magnitude lower than those observed for the pure $\mathrm{Am}(\mathrm{OH})_{3}-\mathrm{H}_{2} \mathrm{O}$ system even at higher $\mathrm{pH}$ (Guillaumont et al. 2003) points to the predominance of ion exchange mechanism in this heterogeneous equilibrium.

The weakly alkaline group of samples, represented by "KE NLOP" and "KC-6" sludges, shows consistently low ${ }^{241} \mathrm{Am}$ levels, which are approximately equal to the Am concentration at $\mathrm{pH}=5.5$. Conversion of the lowest observable ${ }^{241} \mathrm{Am}$ activity level of $\sim 5 \times 10^{-4} \mu \mathrm{Ci} / \mathrm{ml}$ into molar concentration of americium using its specific activity value of $3.43 \mathrm{Ci} / \mathrm{g}$ results in the $6 \times 10^{-10} \mathrm{M}$ value $(\log [\mathrm{Am}]=-9.2)$. 
This number is in good correspondence with ${ }^{241} \mathrm{Am}(\mathrm{OH})_{3} \cdot \mathrm{nH}_{2} \mathrm{O}$ solubility in the mildly alkaline region of $\mathrm{pH}$ as reported by Kim and co-workers. (Kim 1984).

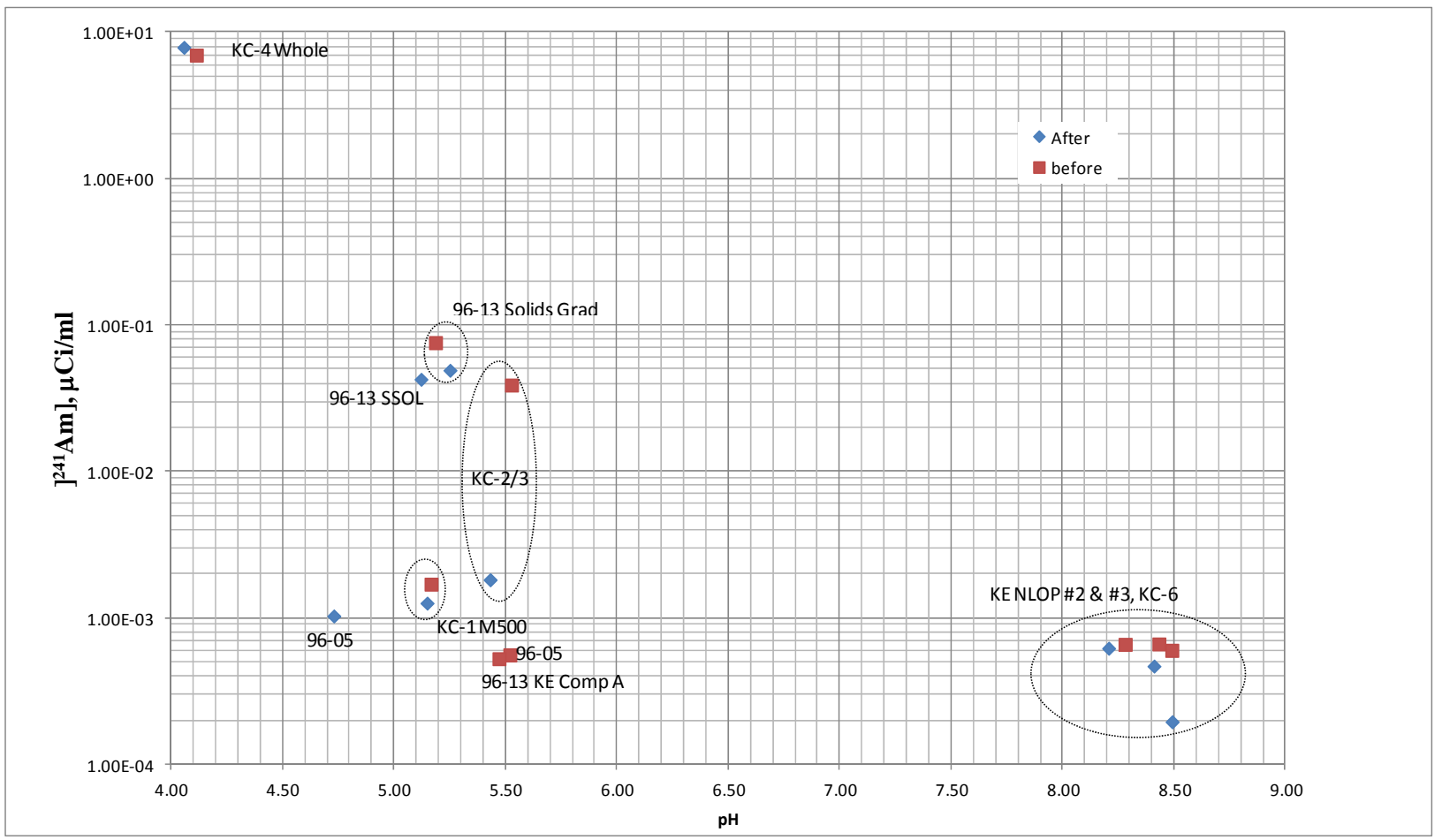

Figure 3.4. $\quad{ }^{241}$ Am Activity Levels in Filtered Sludge Supernatants Before and After Re-Jarring as a Function of $\mathrm{pH}$

${ }^{241} \mathrm{Am}$ behavior in the weakly alkaline $\mathrm{pH}$ range does not resemble the one exhibited by ${ }^{137} \mathrm{Cs}$ as one can see by comparing the respective groups of points in Figure 3.3 and Figure 3.4. There are no poorly soluble Cs compounds known which would restrict its solubility down to sub-nanomolar range of concentrations. It appears that ${ }^{137} \mathrm{Cs}$ behavior is predominantly controlled by its ion exchange interaction with sorption sites of one or several major sludge phases present in the sludge.

Among several nonradioactive major phases composing K Basin sludges, iron(III) and aluminum(III) oxyhydroxides, along with silicate phases such as quartz $\left(\mathrm{SiO}_{2}\right)$, contribute most significantly to the sludge composition. Technical literature search on ${ }^{137} \mathrm{Cs}$ adsorption on metal hydroxide led to a study by Plotnikov and Taurbaeva (1976) which reports radiocesium uptake by freshly prepared and ten-day-old hydroxides of various multivalent metal cations, including those of $\mathrm{Fe}(\mathrm{III})$ and $\mathrm{Al}(\mathrm{III})$. The cited findings are reproduced in Figure 3.5 below. 

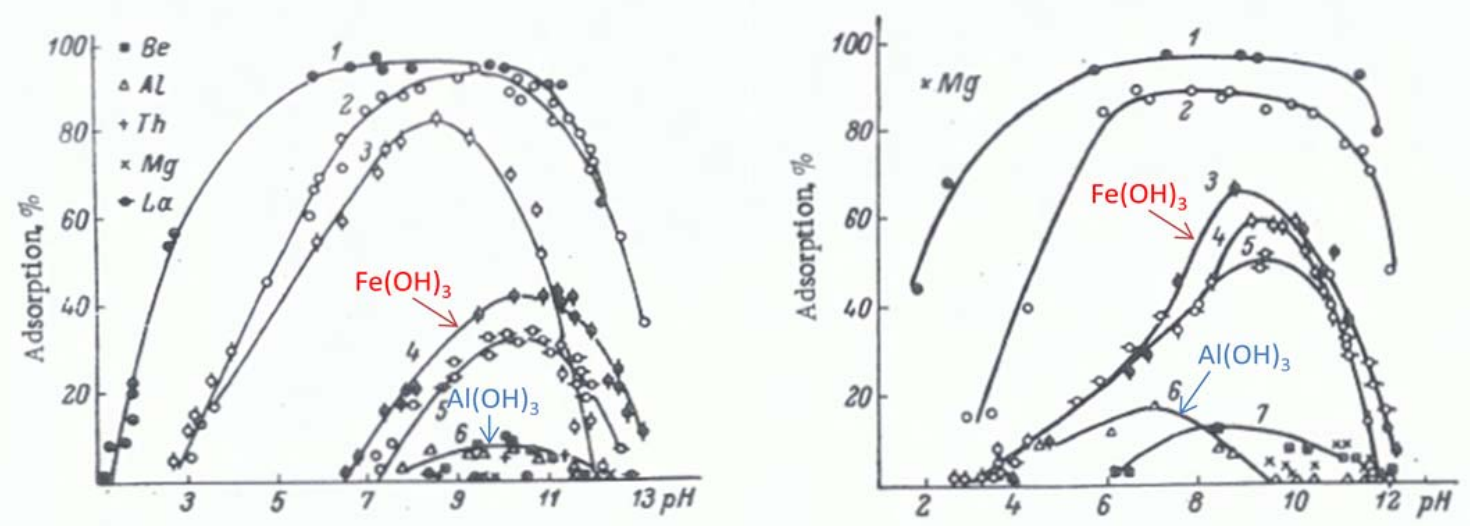

Figure 3.5. Adsorption of ${ }^{137} \mathrm{Cs}$ on Freshly Prepared Metal Hydroxides (left) and on the Metal Hydroxides After Ten Days of Aging (right) as a Function of the $\mathrm{pH}$ of the Solution: $1-\mathrm{Nb}$; 2-Ti; 3 - Fe; 4 - Sn; 5 - Zr; 6-Al; 7-Be, $\mathrm{Mg}$ (curve \#7 is shown for $\mathrm{Be}$ and $\mathrm{Mg}$ on the right plot only)

It is seen that freshly formed $\mathrm{Fe}(\mathrm{OH})_{3}$ and $\mathrm{Al}(\mathrm{OH})_{3}$ do not possess measurable affinity for ${ }^{137} \mathrm{Cs}$ below pH 6.5 and $\sim 7.2$, respectively. However with even modest aging time both materials become much more efficient adsorbents for this radionuclide. Also, their sorption maxima shift to lower $\mathrm{pH}$ values: from $\mathrm{pH} \sim 10.5$ and $\sim 10.0$ to 8.5 and 7.2 for $\mathrm{Fe}(\mathrm{III})$ and $\mathrm{Al}(\mathrm{III})$ hydroxides, respectively. By extrapolation, both sorption maxima are expected to shift further to lower $\mathrm{pH}$ values with a longer aging time. The ascending portions of the adsorption curves are consistent with our ${ }^{137} \mathrm{Cs}$ concentration trend in the weakly acidic $\mathrm{pH}$ range. But they do not explain ${ }^{137} \mathrm{Cs}$ levels in our group of weakly alkaline samples unless an assumption is made that with additional aging time adsorption curves become bimodal or, in other words, develop a second maximum at $\mathrm{pH} \sim 8.8$ with a minimum between two maxima at $\mathrm{pH} \sim 7.4$. This sort of sorption curve $\mathrm{pH}$ profile is not uncommon, as it was observed in the same publication for ${ }^{137} \mathrm{Cs}$ sorption on titanium hydroxide in the presence of $5 \mathrm{mM}$ alkaline-earth metal cations $\left(\mathrm{Mg}^{2+}, \mathrm{Ca}^{2+}\right.$, $\mathrm{Sr}^{2+}$, and $\left.\mathrm{Ba}^{2+}\right)$.

One of the major solid phases in the KE Basin sludges detected previously in the samples examined in this study is a U(VI)-based group of materials that includes metaschoepite, schoepite, becquerelite, and, to lesser extent, sodium uranium hydroxide hydrate and uranophane (Delegard et al. 2011). Therefore, it was of interest to investigate a potential correspondence between ${ }^{137} \mathrm{Cs}$ activity levels in the sludge supernatants and uranium concentration in the sludge. Figure 3.6 depicts this dependence. It is seen that for the samples with very low uranium content in sludge $(0.31 \%)$, the concentration of ${ }^{137} \mathrm{Cs}$ is less than $50 \mathrm{nCi} / \mathrm{ml}$. With a gradual increase in [U], the $\left[{ }^{137} \mathrm{Cs}\right]$ grows linearly (in the $\log \left[{ }^{137} \mathrm{Cs}\right]$ scale) and increases by two orders of magnitude at $16 \%$ of [U]. At much higher uranium concentrations (cluster of six points in the [U] range from 52 to $74 \%$ ), the activity level of ${ }^{137} \mathrm{Cs}$ decreases to an average value of $43 \pm 32 \mathrm{nCi} / \mathrm{ml}$ with no statistically significant trend of $\left[{ }^{137} \mathrm{Cs}\right]$ positive or negative change within this relatively narrow range of [U].

The effect of re-jarring on $\left[{ }^{137} \mathrm{Cs}\right]$ and acidity of supernatants in this uranium-rich group of samples can be assessed by comparison of average values of $\left[{ }^{137} \mathrm{Cs}\right]_{\text {before }}=16 \pm 13 \mathrm{nCi} / \mathrm{ml} \mathrm{at} \mathrm{pH}_{\text {average }}=5.43 \pm 0.16$ and $\left[{ }^{137} \mathrm{Cs}\right]_{\mathrm{after}}=43 \pm 32 \mathrm{nCi} / \mathrm{ml}$ at $\mathrm{pH}_{\text {average }}=5.11 \pm 0.24$. It seems that the five-year storage time for the same group of samples results in both a decrease in the $\mathrm{pH}$ by $\sim 0.3$ units and an increase in radiocesium concentration by a factor of $\sim 2.6$. 


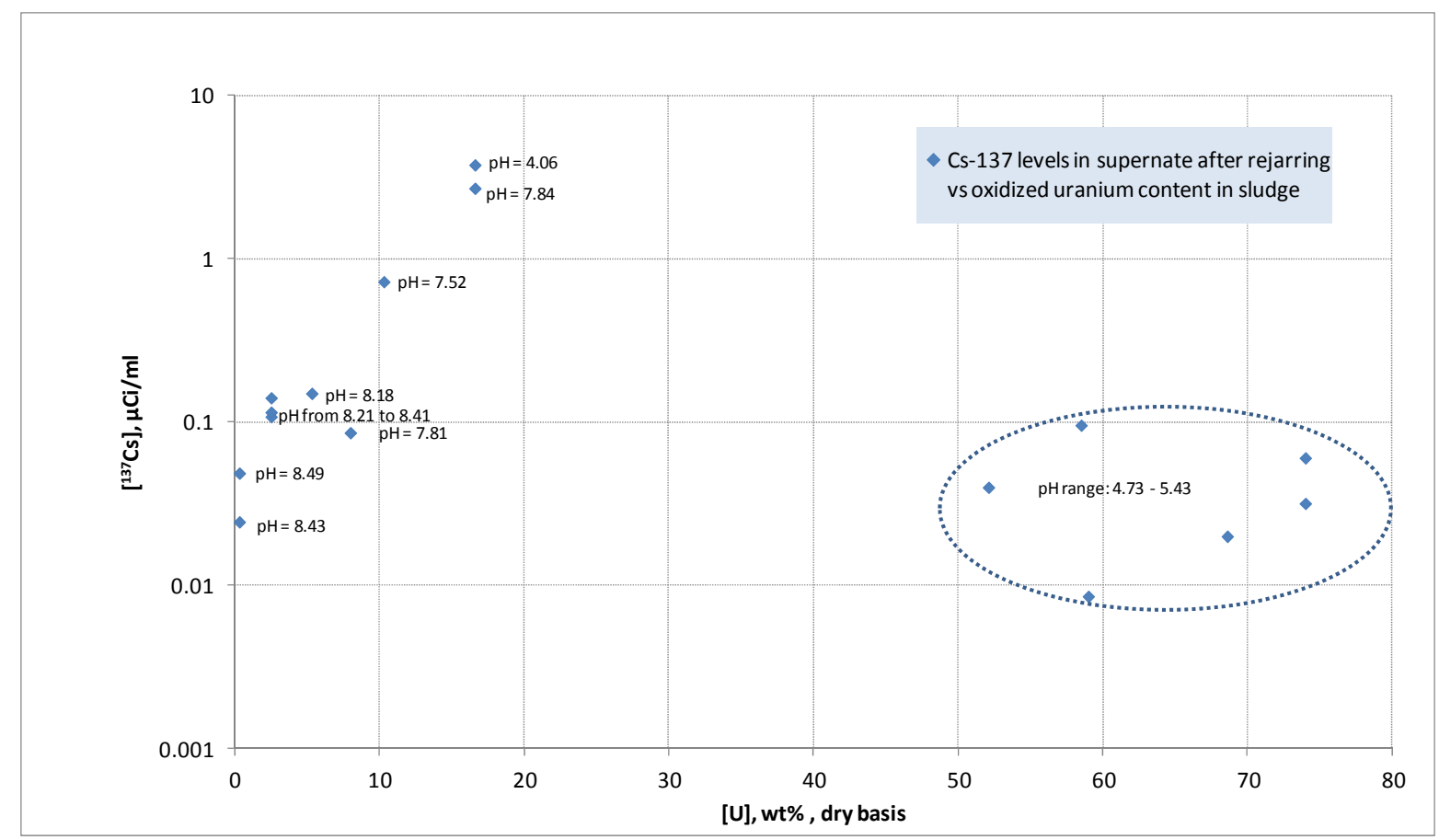

Figure 3.6. $\quad{ }^{137}$ Cs Activity Levels in Filtered Sludge Supernatants After Re-Jarring as a Function of Dry Basis Uranium Concentration

The relationship between $\mathrm{pH}$ of supernatants and uranium concentration in sludge (Figure 3.7) for all 16 wet samples with known [U] after re-jarring clearly shows effect of acidification of water contacting sludge with growing uranium content in the solid phase.

"KC-4 Whole" represents a very notable exception from this trend. The origin of its excessive acidity still remains unknown, although after five years since previous observation, the $\mathrm{pH}$ of this sludge sample has increased by $\sim 0.5 \mathrm{pH}$ units. This $\mathrm{pH}$ change in the process of storage and aging occurred most likely by gradual dissolution of the $\mathrm{U}(\mathrm{VI})$ phases as the least resistant ones to weakly acidic treatment compared to the $\mathrm{Fe}(\mathrm{III}), \mathrm{Al}(\mathrm{III})$, and silicate phases. This assumption is consistent with the observation that the filtrate of "KC-4 Whole" has a very intense yellow color, which is typical for significant concentrations of U(VI) in solution. 


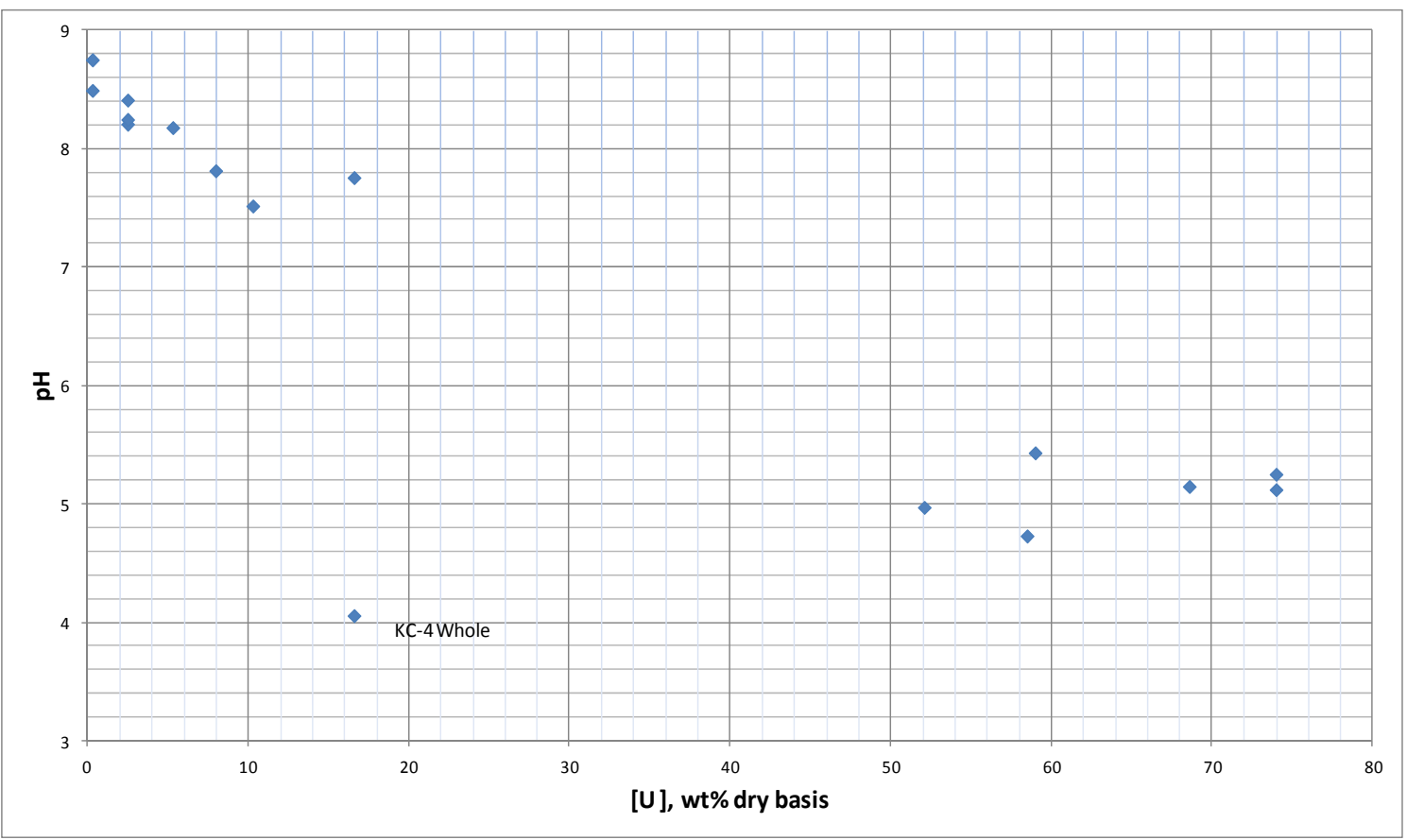

Figure 3.7. Sludge $\mathrm{pH}$ After Re-Jarring as a Function of Dry-Basis Uranium Concentration

\subsection{Gel Formation in the Mixture of Unfiltered Supernatants}

Thirty-three samples with unfiltered water supernatants were received from SAL for filtration and aliquoting for $\mathrm{pH}$ and GEA measurements. Each sample contained from $\sim 4$ to $\sim 9 \mathrm{ml}$ of aqueous phase which had been in contact with the respective sludge material before its separation from the respective jar. Most of the samples were colorless or pale yellow with very little or no solid phase present. Several samples had significant amounts of finely dispersed solid phase present in solution with a very slow sedimentation rate. All samples were filtered through a $0.2-\mu \mathrm{m}$ syringe filter membrane to remove the suspended or colloidal material. In two cases ("KC-4 Whole_Before" and "KC-4 Whole_After") the filtration was extremely difficult to perform and it required use of four large-surface-area syringe filters to produce $2.0 \mathrm{ml}$ of clear liquid for GEA and $0.5 \mathrm{ml}$ for the $\mathrm{pH}$ measurement. The filtrates of these particular samples were intense yellow for the "KC-4 Whole_Before" and somewhat less intense in color for the "KC-4 Whole_After." Both samples were the most yellow among other remaining samples after filtration and had the lowest $\mathrm{pH}$ measured in the present and prior (Delegard et al. 2011) testing. In both cases significant foaming was observed in the process of filtration during collection of filtered portions of these particular samples.

The GEA and $\mathrm{pH}$ sample preparation took only $2.5 \mathrm{ml}$ of the filtered liquid per sample. The remaining (unfiltered) portions of all 33 solutions were combined into an open plastic container and were left over a weekend for evaporation. The starting volume of the combined sample was $\sim 100 \mathrm{ml}$. Three days later, the remaining volume was $\sim 40-45 \mathrm{ml}$. One more day of evaporation (with a higher linear air flow rate) resulted in additional volume reduction to $\sim 10-15 \mathrm{ml}$. At that stage, a relatively thick film of gelatinous (or colloidal) material was observed on the surface of the remaining liquid. Its color was pale tan. No photographs were taken to document formation and visual appearance of this material as the cognizant scientist was not aware of the importance of this effect at the time of its observation. One more day of evaporation caused complete drying of $\sim 70 \%$ of the container material, with the remaining $~ 30 \%$ of material present as wet residue. The completely dry portions were red-brown, while the still-wet areas 
were tan-colored and had a very soft consistency as probed by a 1-ml pipette tip. A few milligrams of the still wet material were dispersed in $\sim 1.5 \mathrm{ml}$ of deionized (DI) water with visually complete dispersion achieved in 2-3 minutes of gentle agitation. The liquid color was pale tan. This "diluted" sample was filtered to see to what extent the tan fraction contributes to the difficulty of filtration and to the filter clogging. Filtration started with moderate resistance for the first $0.5 \mathrm{ml}$ and then slowed down significantly for the remaining $1 \mathrm{ml}$ of the unfiltered liquid. The filtrate was completely colorless. The filtered solids color was pale tan.

Twenty to twenty-five $\mathrm{ml}$ of DI water were added to the partially dried solids and the container content was gently agitated by a disposable pipette in an attempt to reconstitute the material to observe and examine in more detail the gelatinous film found on the water surface after four days of drying. However, no signs of the film formation were observed in this and several subsequent gradual evaporation runs.

Another attempt to reproduce gelatinous compound formation was undertaken three months after rejarring using the 33 filtered supernatant samples returned from GEA measurements. All samples were kept in their original containers (20-ml polyethylene vials) with the container lids removed and the vials' contents gradually evaporated under a steady air flow within a radiological fume hood. The samples' volumes were observed to reduce approximately at the same rate as described in the second preceding paragraph. Visual observations were made each working day until complete evaporation of the liquids. No gel-like material was found to form at any stage of evaporation in any of the samples tested.

These observations of gel formation during supernatant handling are included here in case they add further insight to the observations of the source of thin gel layers noted in recently taken K Basin sludge samples (Fiskum el al. 2012) 



\subsection{Conclusions}

- $\quad{ }^{137} \mathrm{Cs}$ concentration values given in the sludge characterization reports bracket the values obtained in the process of re-jarring of the archive sludges. The radiocesium values for the "Before," "During," and "After" transfers of KE Basin sludge to the KE Weasel Pit (from Table 4-2 in HNF-SD-SNF-TI-009; Pearce 2001) are at the low end of those observed in this round of archive sludge measurements, while the concentrations in the characterization of the $\mathrm{K}$ Basin waters (data from Table 4-1 in HNF-SD-SNF-TI-009; Pearce 2001) are at the high end of those observed in the archive sludge. Therefore, no evidence for leaching or displacement of ${ }^{137} \mathrm{Cs}$ from the sludge solids to the supernatant solution can be seen with aging.

- $\quad{ }^{137} \mathrm{Cs}$ activity levels in supernates of archived sludge samples appear to be a sensitive function of $\mathrm{pH}$. The following relationships were established by the linear least squares analysis of the obtained data:

$$
\begin{aligned}
& \text { o } \log \left[{ }^{137} \mathrm{Cs}, \mu \mathrm{Ci} / \mathrm{ml}\right]=-(1.82 \pm 0.13) \mathrm{pH}+(7.87 \pm 0.64) \text { for } \mathrm{pH} \text { range from } 4.06 \text { to } 5.52 \\
& \text { o } \log \left[{ }^{137} \mathrm{Cs}, \mu \mathrm{Ci} / \mathrm{ml}\right]=-(2.17 \pm 0.20) \mathrm{pH}+(17.3 \pm 1.7) \text { for } \mathrm{pH} \text { range from } 7.66 \text { to } 8.80 .
\end{aligned}
$$

- No rigorous comparison of ${ }^{137} \mathrm{Cs}$ concentrations measured in recent sludge settling tests can be made with the data obtained in this study because of insufficient overlapping of $\mathrm{pH}$ regions (6.34-7.72 for settling tests vs. 4.06-5.52 range and 7.49-8.80 range for the re-jarring study).

- Sludge disturbance in the process of re-jarring does not increase ${ }^{137} \mathrm{Cs}$ activity level in 14 of the 16 sludge supernatants examined in this study. This conclusion is based on examination of ${ }^{137} \mathrm{Cs}$ activity ratio for the respective samples before and after-re-jarring as shown below:

o Average $\left[{ }^{137} \mathrm{Cs}\right]_{\mathrm{after}} /\left[{ }^{137} \mathrm{Cs}\right]_{\text {before }}$ ratio for all 16 samples: $1.99 \pm 3.12 / \sqrt{ } 16=1.99 \pm 0.78$

o The same ratio after exclusion of "96-05" and "96-13 Comp A" from averaging: $0.87 \pm 0.19 / \sqrt{ } 14=0.87 \pm 0.05$

0 The latter value of 0.87 could be caused by addition of new portions of DI water to old jars to remobilize sludge portions attached to walls and the bottom of the container for more efficient sludge material transfer to the new container (i.e., a minor dilution factor)

o Average $\left[{ }^{137} \mathrm{Cs}\right]_{\mathrm{after}} /\left[{ }^{137} \mathrm{Cs}\right]_{\text {before }}$ ratio for six acidic samples: $3.91 \pm 4.71 / \sqrt{ } 6=3.91 \pm 1.92$

o Average $\left[{ }^{137} \mathrm{Cs}\right]_{\text {after }}\left[{ }^{137} \mathrm{Cs}\right]_{\text {before }}$ ratio for four acidic samples (after exclusion of " $96-05$ " and “96-13 Comp A" from averaging): $0.95 \pm 0.23 / \sqrt{ } 4=0.95 \pm 0.12$

o Average $\left[{ }^{137} \mathrm{Cs}\right]_{\text {after }} /\left[{ }^{137} \mathrm{Cs}\right]_{\text {before }}$ ratio for 10 weakly alkaline samples: $0.84 \pm 0.17 / \sqrt{ } 10=0.84 \pm 0.05$.

- $\quad{ }^{241} \mathrm{Am}$ activity levels decrease very steeply (4.2 orders of magnitude) with $\mathrm{pH}$ elevation from 4.06 to 5.52, a slope of decrease of three orders of magnitude per unit $\mathrm{pH}$ increase, down to $50 \mathrm{nCi} / \mathrm{ml}$ and remain at this level for the weakly alkaline archive sludge supernatants. 



\subsection{References}

Baker RB, TL Welsh and BJ Makenas. 2000. Sampling and Analysis Plan for the Sludge from the 105-Basins to Support Transport to and Storage in T Plant. HNF-6479, Rev. 0, Fluor Hanford, Richland Washington.

Billing JM, CA Burns, CD Carlson, DS Coffey, RC Daniel, CH Delegard, SK Fiskum, PJ MacFarlan, KN Pool, AJ Schmidt, RW Shimskey, and LA Snow. 2011. Settling Studies of KW Basin Settler Sludge from SCS-CON-230 and Settler Sludge Simulant (230). PNNL-20884, Pacific Northwest National Laboratory, Richland, WA.

Delegard CH, AJ Schmidt, and JW Chenault. 2011. Characteristics of KE Basin Sludge Samples Archived in the RPL - 2007. PNNL-17078, Rev. 1, Pacific Northwest National Laboratory, Richland, WA.

Delegard CH, AJ Schmidt, and JW Chenault. 2004. Mechanical Properties of K Basin Sludge Constituents and Their Surrogates. PNNL-14947, Pacific Northwest National Laboratory, Richland, WA.

Fiskum SK, JM Billing, CA Burns, AJ Casella, RW Shimskey, LA Snow, CD Carlson, DS Coffey, LA Middleton, and AJ Schmidt. 2012. Integrated Report for the Further Evaluation of Total Organic Carbon, Particle Size Distribution, and Gel Formation in Selected Samples of K Basin Sludge. PNNL-21447, Pacific Northwest National Laboratory, Richland, WA.

Fiskum SK, OP Bredt, CA Burns, CD Carlson, DS Coffey, RC Daniel, PJ MacFarlan, KN Pool, AJ Schmidt, GJ Sevigny, RW Shimskey, and LA Snow. 2010. Stage 1 and Stage 2 Settling Studies of K-Basin Containerized Sludge. PNNL-19213, Pacific Northwest National Laboratory, Richland, WA.

Guillaumont R, J Fuger, I Grenthe, T Fanghanel, V Neck. 2003. Update on the Chemical Thermodynamics of Uranium, Neptunium, Plutonium, Americium and Technetium.. Edited by FJ Mompean, M Illemassene, C Domenech-Orti, and K Ben Said. OECD Nuclear Energy Agency.

Kim JI, M Bernkopf, C Lierse, and F Koppold. Hydrolysis reactions of Am(III) and Pu(VI) ions in near-neutral solutions. In: Geochemical Behavior of Disposed Radioactive Waste. (Barney, G. S., Navratil, J. D., Schulz,W. W., eds.) ACS Symp. Ser.,Vol. 246, Washington, ACS (1984), pp. 115-134.

Makenas BJ, TL Welsh, RB Baker, EW Hoppe, AJ Schmidt, J Abrefah, JM Tingey, PR Bredt, and GR Golcar. 1997. Analysis of Sludge from Hanford K East Basin Canisters. HNF-SP-1201, DE\&S Hanford, Inc., Richland, WA.

Mellinger GB, CH Delegard, AJ Schmidt, and GJ Sevigny. 2004. Evaluation and Recommendation of Waste Form and Packaging for Disposition of the K East Basin North Loadout Pit Sludge. PNNL-14741, Pacific Northwest National Laboratory, Richland, WA.

Pearce KL. 2001. 105-K Basin Material Design Basis Feed Description for Spent Nuclear Fuel Project Facilities, Volume 2, Sludge. HNF-SD-SNF-TI-009, Rev 4, Volume 2, Fluor Hanford, Richland, WA.

Plotnikov VI, TI Taurbaeva. 1976. Adsorption of Cesium-137 by Metal Hydroxides. Soviet Radiochemistry, 17(2): 340-345. 
Schmidt AJ, RT Hallen, DS Muzatko, and SR Gano. 2004. KE Basin Sludge Flocculant Testing. PNNL-14730, Pacific Northwest National Laboratory, Richland, WA. 


\section{Appendix A}

Addition of "SFEC 96-04" Fuel Sample to the Inventory of Pre-2004 K Basin Samples 



\section{Appendix A}

\section{Addition of “SFEC 96-04” Fuel Sample to the Inventory of Pre-2004 K Basin Samples}

\section{A.1. Sample Identification and Re-jarring}

In accordance with the CHPRC BTR decision to include sample SFEC 96-04 in the group of "Key Samples to be Maintained" for continued archive, this U metal fuel sample was identified and found to be packaged into a 40-ml glass vial labeled as 96-04 (see Figure A.1).
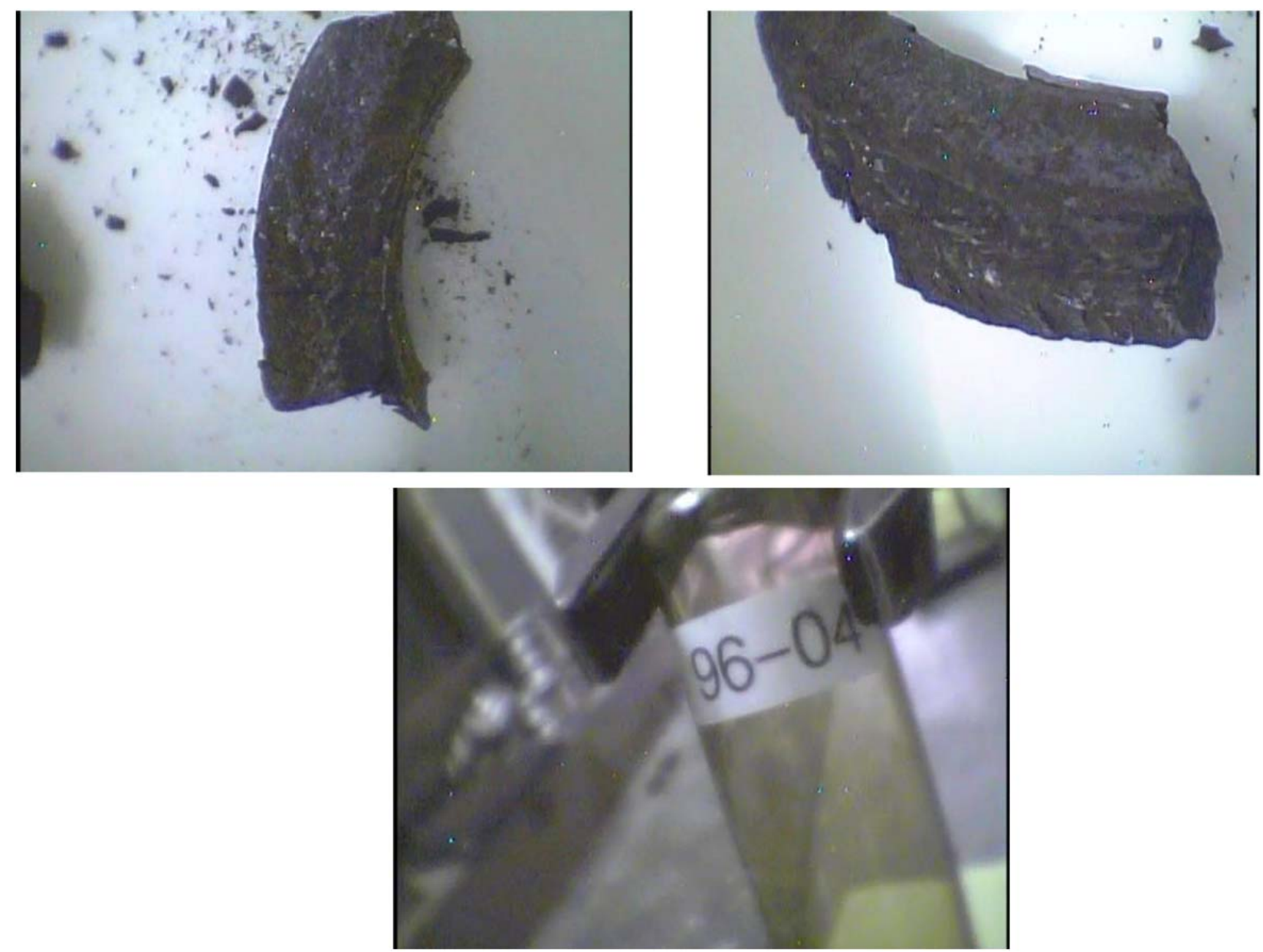

Figure A.1. SFEC 96-04 U Metal Fuel Sample as Found During May 17, 2012 Inventory and Inspection of Old Fuel Samples Thought to be Related to a Different Project

This fuel sample at the moment of inspection consisted of two pieces; its weight (fuel plus cladding) was $66.5569 \mathrm{~g}$. Subsequent review of $\mathrm{K}$ Basin records indicated with reasonable confidence that it is Mark IV fuel (lower enrichment) from N Reactor fuel element $2540 \mathrm{KE}$ that was stored in the KE Basin. Figure A2 illustrates the prior sectioning operations conducted on this fuel element. 


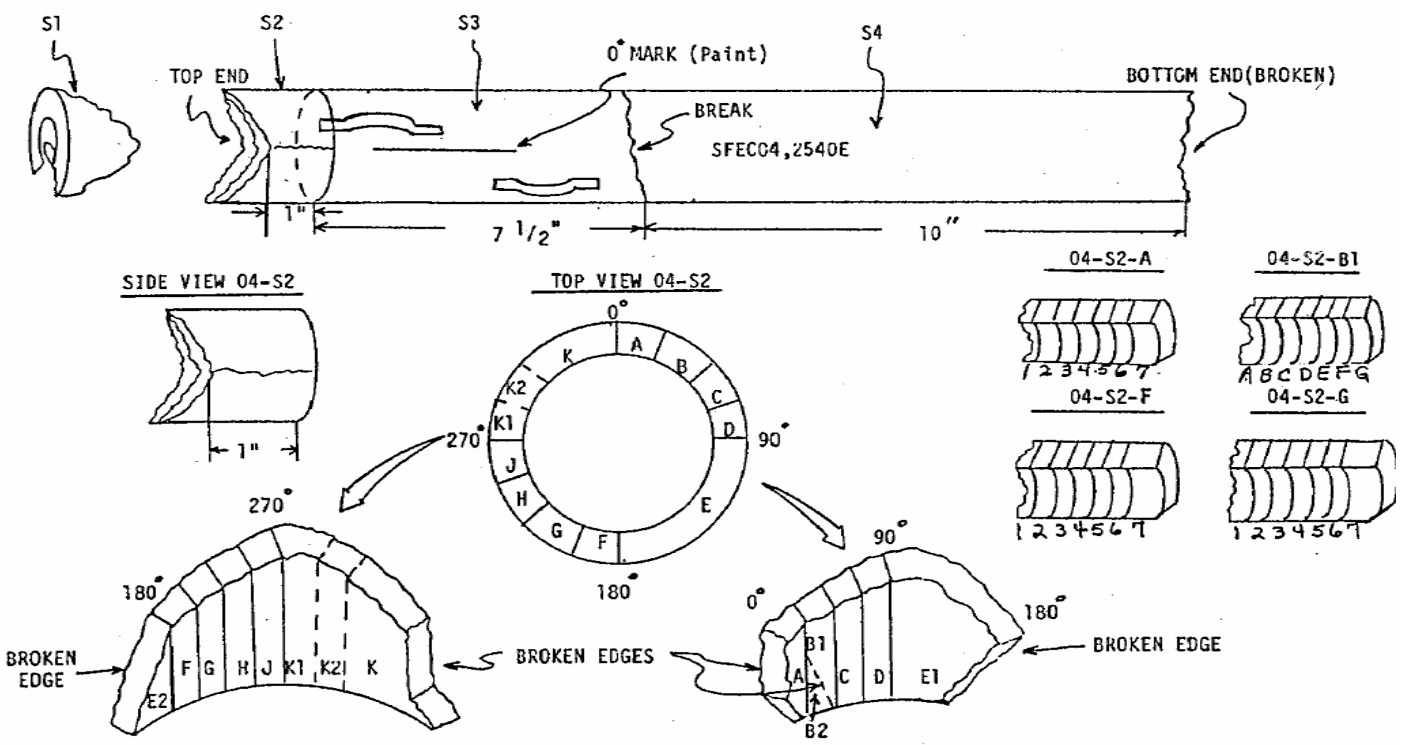

Figure A.2. Fuel Element SFEC04, 2540E from KE Basin (based on Fig 3.1 of Delegard et al. 2004)

The original sample-containing vial showed some signs of glass degradation and it was decided to transfer the fuel pieces to new glass vial container of identical geometry. In the process of re-jarring, one of two $U$ metal pieces broke into two fragments, making it three major pieces of $U$ metal in the sample. The sample appearance after re-jarring is shown in Figure A.3. The net weight of the sample after re-jarring was $66.5 \mathrm{~g}$, which represents $99.9 \%$ transfer efficiency from the original container.

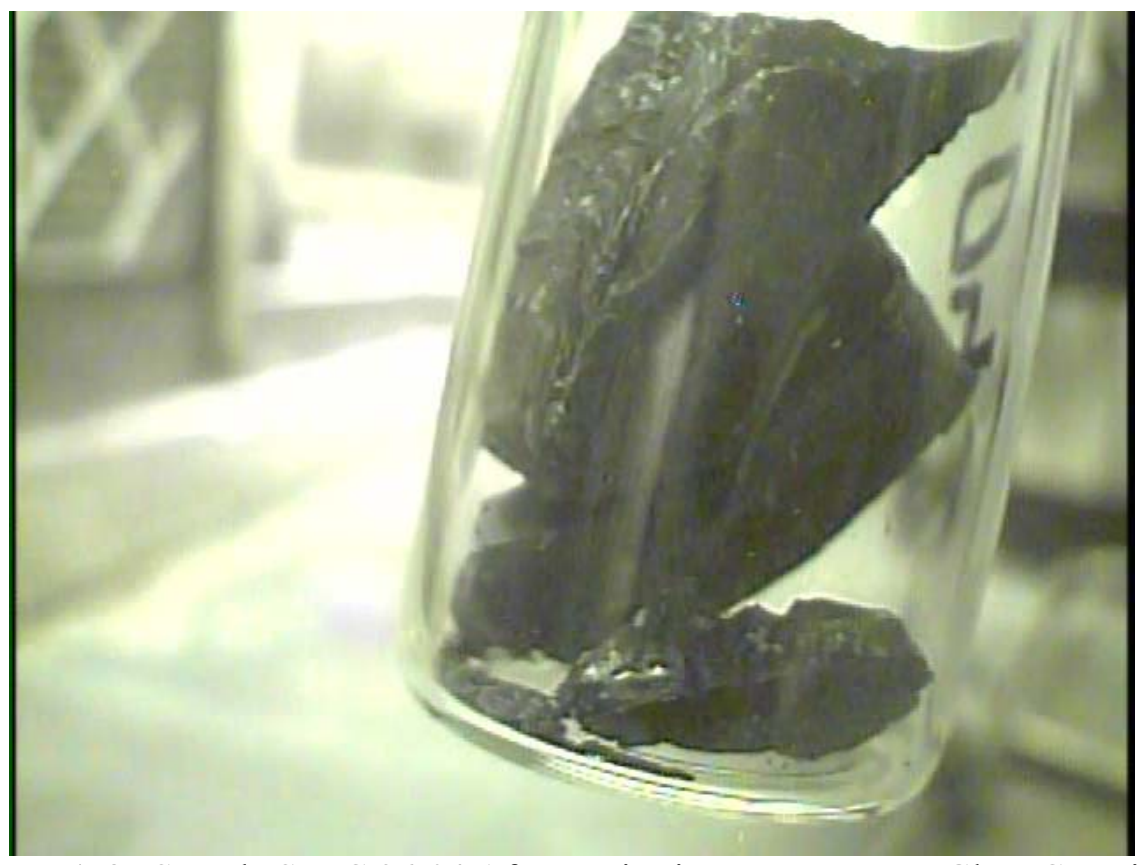

Figure A.3. Sample SFEC 96-04 After Re-jarring It Into a New Glass Container

This fuel sample has potential value for STP Phase 2 as test material to examine size reduction (e.g., Hockmeyer grinder) and for use in warm water oxidation testing to confirm the rate enhancement 
factor. This sample was relocated to join the Pre-2004 K Basin samples that are being monitored and maintained.

\section{A.2. Labeling Nomenclature on Vial with Fuel Pieces Labeled SFEC 96-04 ${ }^{1}$}

The nomenclature indicated on the label of the subject sample vial is not clear as to its specific linkage to different sampling campaigns and corresponding sample numbers. In 1996 there were two KE Basin sampling campaigns; one campaign was for canister sludge and the other for damaged spent fuel elements:

- The canister sludge sampling campaign included a primary sludge sample designated "96-04." This sample was taken from the east barrel of the KE Basin spent fuel canister located in cubicle 2711 (HNF-SP-1201, Table 3.1) and shipped to the 327 and 325 Building hot cell facilities. Note that the sludge sampling system used at KE included a sample extraction tube with ports sized no larger than $1 / 4$ inch (e.g., HNF-SP-1201, Figure 3.1).

- The fuel sampling campaign included a damaged spent fuel element taken and shipped to the same hot cell facilities (for further sectioning/sampling) designated "SFEC04, 2540E." This spent fuel element was taken from the east barrel ("E") of the KE Basin fuel canister located in cubicle 2540 that was shipped to hot cell laboratories in the Single Fuel Element Canister \#04 or "SFEC04." The fuel element was later sectioned into sub-samples per References 3 and 4, which resulted in the cutting diagram provided in PNNL-14947.

Given the restrictions ( $1 / 4$-inch ports) on the KE Basin sludge collection system sampling tube, sludge sample 96-04 was composed of particulate less than $1 / 4$ inch in diameter. It follows that the fuel pieces in the subject vial, which are larger than $1 / 4$ inch, are from fuel element SFEC04, 2540E and are not related to the canister sludge sample designated 96-04. The reason for the vial label using the reference to "96-04" seems to be either: 1) a coincidence in trying to choose a random sample number (but inadvertently picking one the same as used in the sludge campaign) or 2) the result of a labeling error. Note that both the choices of the fuel and sludge canisters for sampling were discussed in Reference 1 .

\section{References}

1. BJ Makenas et al., "Choices of Canisters and Elements for the First Fuel and Canister Sludge Shipment from K East Basin.” WHC-SD-SNF-SM-003, Rev. 0, March 1996.

2. BJ Makenas, et al., "Analysis of Sludge from Hanford K East Basin Canisters." HNF-SP-1201, September 1997.

3. SA Chastain (DESH) to JM Seay (BWHC), "Examination Requirements for Fuel Element 2540E," DESH-9656454, January 17, 1997.

4. J. Abrefah, “Test Instruction Entitled Sectioning the Damaged Top End of SNF-Element SFEC04." 2540E, SNF-CT-093, Rev. 0, November 12, 1996.

5. CH Delegard, et al., "Mechanical Properties of K Basin Sludge Constituents and Their Surrogates." PNNL-14947, November 2004.

\footnotetext{
${ }^{1}$ This section is provided by Ron Baker (CHPRC) soon after the sample was added to the inventory of the Pre-2004 $\mathrm{K}$ Basin samples.
} 

Appendix B

Observations of Resin Beads After Re-Jarring 



\section{Appendix B}

\section{Observations of Resin Beads After Re-Jarring}

Before re-jarring it was difficult to observe appearance of most sludge samples due to a glass darkening effect which had gradually developed during the samples storage in a hot cell environment. Placing sludge samples in new containers greatly improved their visibility through walls of new jars. In accordance with Test Instruction sludge observations in the process of re-jarring and after re-jarring were documented in Table 3 of 53451-TI42 and reproduced here as scanned images of the table (Figures B.1 and B.2 below).

Several samples contained significant fractions of organic ion-exchange resin material (KC-6, KC-6 New X, KC-6 New Y and to a lesser extent 96-05). It was not possible to judge about presence of zeolite like materials in these and other sludge samples due to interfering effect of finely dispersed iron hydroxide as one of the major constituents in all wet samples. In the future it would be desirable to monitor the radionuclide levels and acidity of the OIER- and zeolite-rich sludge samples more frequently to have a better understanding of variability of these parameters under high radiation and intense radiolysis conditions.

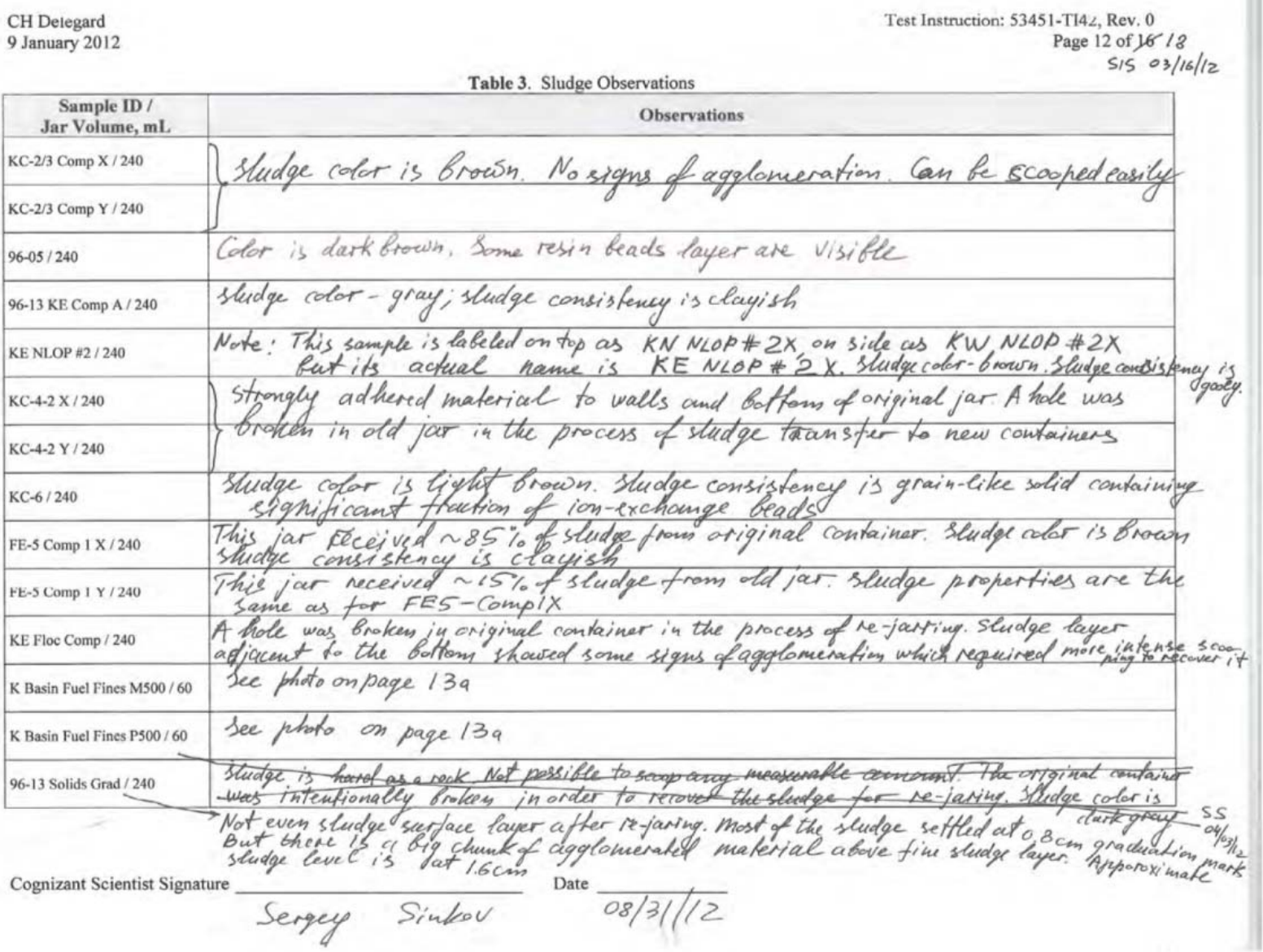

Figure B.1. Sludge Observations for the First Twelve Wet Samples (scan from Table 3 of Test Instruction 53451-TI42) 


\begin{tabular}{|c|c|}
\hline $\begin{array}{l}\text { CH Deiegard } \\
9 \text { January } 2012\end{array}$ & $\begin{array}{r}\text { Test Instruction: } 53451-T 142, \text { Rev. } 0 \\
\text { Page } 13 \text { of } 16 \\
\text { SIS 0.3 }\end{array}$ \\
\hline $\begin{array}{l}\text { Sample ID / } \\
\text { Jar Volume, mL }\end{array}$ & Observations \\
\hline $96-13 \mathrm{SSOL} / 240$ & $\begin{array}{l}\text { This sample was removed tram old jar only after braking the old container apart. } \\
\text { Phe sludge sanele was partically crushed, fut still contains large chumles of agelon }\end{array}$ \\
\hline KC-4 Whole / 240 & $\begin{array}{l}\text { Supernatant was not dear afher aqfitation of gel jar and sevenal days of sedimentutian } \\
\text { supernatenot coldr was milky gray brownish. }\end{array}$ \\
\hline KE Pit / 240 & Color is dark brown. Finely granulated material \\
\hline KE NLOP $\# 1 / 240$ & $\begin{array}{l}\text { Sludge color is frown. Sludge consistency is doy with some presence of sand-like } \\
\text { traction }\end{array}$ \\
\hline KE NLOP $\# 3 / 240$ & sludge color is frewn. In this sample more significont sand-like fraction is pres: \\
\hline FE-3 Comp 1/240 & $\begin{array}{l}\text { Coffee ground consisfency. Some agqlowaration is visifle. Two big chunks are } \\
\text { sithing on top of the dry matetial }\end{array}$ \\
\hline $\mathrm{KC}-4 \mathrm{P} 250 / 240$ & Color is Prowin. Finely gramulated material \\
\hline KC-1 M500/ 240 & Sludge color is light gray. Sludge consistency is clou-like. \\
\hline SNF Comp Stl Study / 60 & \\
\hline Test 3 Residue / 60 & \\
\hline $96-13$ Settling Study / 60 & $\begin{array}{l}\text { Agglomerated material. Particles are upto } 3 / 4 \text { inch in diameter } \\
\text { color is gray }\end{array}$ \\
\hline KC-6 New X/240 & \} Aludge color is brown. Both samples visibly contain a significont \\
\hline KC-6 New Y / 240 & chom of rontexcronge reads and are easy to homogenize \\
\hline
\end{tabular}

cognizant Scientist Signature Sergey Sinlov Date $08 / 31 / 12$

Figure B.2. Sludge Observations for the Remaining Nine Wet Samples (scan from continuation of Table 3 of Test Instruction 53451-TI42) 


\section{Distribution*}

No. of

Copies

7 CH2M Hill Plateau Remediation Company

RB Baker

JO Honeyman

ME Johnson

WW Rutherford

JP Sloughter

NJ Sullivan

FE Wickstrand
No. of

Copies
A3-06

A3-06

A $0-26$

A3-06

A3-06

A3-06

R1-29
14 Pacific Northwest National Laboratory

MM Anderson

P7-28

CD Carlson

P7-25

JW Chenault

$\mathrm{CH}$ Delegard

P7 -25

WC Dey

P7-25

SK Fiskum

RJ Orth

J2-56

P7-25

P8-60

K9-09

P8-60

AJ Schmidt

P7-25

SI Sinkov

P7-22

MR Smoot

P7-25

Project File

K3-52

Information Release (pdf)

*All distribution will be made electronically. 


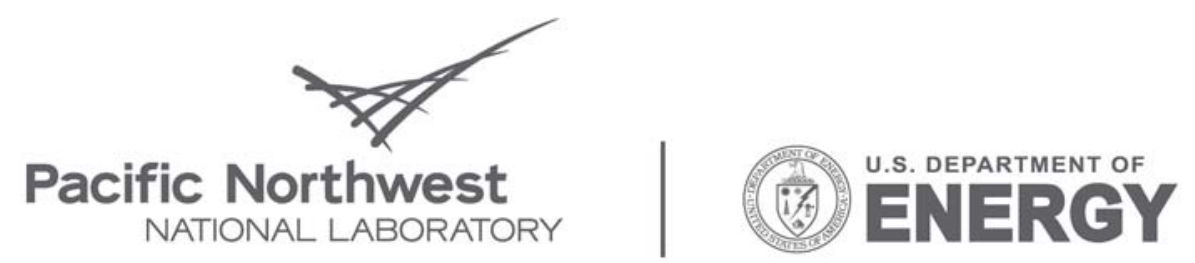

Proudly Operated by Battelle Since 1965

902 Battelle Boulevard

P.O. Box 999

Richland, WA 99352

1-888-375-PNNL (7665)

www.pnl.gov 